\title{
Review \\ Current State of Analgesia and Sedation in the Pediatric Intensive Care Unit
}

\author{
Chinyere Egbuta and Keira P. Mason *(D)
}

check for

updates

Citation: Egbuta, C.; Mason, K.P. Current State of Analgesia and Sedation in the Pediatric Intensive Care Unit. J. Clin. Med. 2021, 10, 1847. https://doi.org/10.3390/jcm10091847

Academic Editor: Won Ho Kim

Received: 27 February 2021

Accepted: 20 April 2021

Published: 23 April 2021

Publisher's Note: MDPI stays neutral with regard to jurisdictional claims in published maps and institutional affiliations.

Copyright: (c) 2021 by the authors. Licensee MDPI, Basel, Switzerland. This article is an open access article distributed under the terms and conditions of the Creative Commons Attribution (CC BY) license (https:// creativecommons.org/licenses/by/ $4.0 /)$.
Department of Anesthesiology, Critical Care and Pain Medicine, Harvard Medical School, Boston Children's Hospital, 300 Longwood Ave., Boston, MA 02115, USA; Chinyere.Egbuta@childrens.harvard.edu

* Correspondence: Keira.Mason@childrens.harvard.edu; Tel.: +1-(617)-355-2339

\begin{abstract}
Critically ill pediatric patients often require complex medical procedures as well as invasive testing and monitoring which tend to be painful and anxiety-provoking, necessitating the provision of analgesia and sedation to reduce stress response. Achieving the optimal combination of adequate analgesia and appropriate sedation can be quite challenging in a patient population with a wide spectrum of ages, sizes, and developmental stages. The added complexities of critical illness in the pediatric population such as evolving pathophysiology, impaired organ function, as well as altered pharmacodynamics and pharmacokinetics must be considered. Undersedation leaves patients at risk of physical and psychological stress which may have significant long term consequences. Oversedation, on the other hand, leaves the patient at risk of needing prolonged respiratory, specifically mechanical ventilator, support, prolonged ICU stay and hospital admission, and higher risk of untoward effects of analgosedative agents. Both undersedation and oversedation put critically ill pediatric patients at high risk of developing PICU-acquired complications (PACs) like delirium, withdrawal syndrome, neuromuscular atrophy and weakness, post-traumatic stress disorder, and poor rehabilitation. Optimal analgesia and sedation is dependent on continuous patient assessment with appropriately validated tools that help guide the titration of analgosedative agents to effect. Bundled interventions that emphasize minimizing benzodiazepines, screening for delirium frequently, avoiding physical and chemical restraints thereby allowing for greater mobility, and promoting adequate and proper sleep will disrupt the PICU culture of immobility and reduce the incidence of PACs.
\end{abstract}

Keywords: analgesia; sedation; PICU; critically ill pediatric patient; PICU-acquired complications; delirium; withdrawal

\section{Introduction}

Despite an increase in acuity and medical complexity of pediatric patients in the intensive care unit, the last two decades have demonstrated a significant drop in patient mortality [1,2]. This success has been in large part a consequence of technological advancements in physiological monitoring and interpretation, invasive testing, and complex medical procedures, many of which usually require a combination of analgesia, anxiolysis, amnesia, and sedation [3,4]. Balancing this combination of analgesia and sedation is challenging for this diverse spectrum of age, maturity (developmental and emotional), and medical complexity [5]. Currently, the incidence of PICU acquired complications (PAC) outnumbers the rate of PICU mortality. Improvements in sedation delivery have been shown to decrease the incidence of physical restraints, post-traumatic stress disorder, oversedation, delirium, and neuromuscular weakness [6].

This review will present all the most up-to-date and relevant literature that addresses important aspects of PICU (and adult-related when relevant) sedation: national and international sedation guidelines, pharmacodynamics and pharmacokinetics of analgosedative drugs, sedation and analgesia assessment rubrics, pain management, goal-directed sedation strategies, adverse events and side effects, the need for neuromuscular blockade, and 
optimal analgesic and sedation practices. The authors searched PubMed, Medline, and the Boston Children's Hospital medical e-library using the following search terms: sedation in critically ill patients / pain management in the intensive care unit (ICU)/current practices in analgesia and sedation solely at first, then further specifying pediatric patients. The authors also used supplementary search methods such as assessing the similar articles section in PubMed search results and the reference lists of selected studies. The authors included both pediatric and adult studies that are most relevant to clinical practice, while highlighting studies that were published after 2000. Understanding the factors involved in attaining the right balance of adequate analgesia and optimal sedation guided by therapeutic targets that evolve with the changes in each patient's medical condition is key to reducing PACs as well as improving clinical outcomes and functional recovery in critically ill pediatric patients [6].

\subsection{National and International Analgesia and Sedation Guidelines}

In 2006, the United Kingdom Paediatric Intensive Care Society Sedation, Analgesia and Neuromuscular Blockade Working Group, a multi-disciplinary expert panel, used a modified Delphi technique to create consensus guidelines on sedation, analgesia, and neuromuscular blockade in critically ill children. The panel warned that the quality of evidence available in the literature to support these recommendations is poor and that there is little evidence to guide PICU staff with the common clinical problems of tolerance, withdrawal, and the patient who requires long-term sedation or who are difficult to sedate with standard agents [7,8]. In 2016, a multidisciplinary group of experts from members of the European Society of Paediatric and Neonatal Intensive Care (ESPNIC) produced a position statement to help guide professionals in the assessment and reassessment of the effectiveness of treatment interventions for pain, distress, inadequate sedation, withdrawal syndrome, and delirium [9].

A retrospective study evaluated the pharmaceutical management of sedation, analgesia, and neuromuscular blockade medications administered to 66,343 children in 161 ICUs in the United States between 2009 and 2016. The durations of opiate and sedative administration were associated with predicted complications of tolerance and withdrawal. Several medications were dispensed in conflict with Food and Drug Administration (FDA) warnings [10]. Surveys of analgosedative practices in PICUs have demonstrated a wide variability in clinical practice typically associated with individual provider preference, local culture, the use of multiple drug combinations and classes, variations in dosing and routes of administration, as well as the use of off-label drugs [11-14]. The relative scarcity of high quality pediatric studies and randomized controlled trials in the area of analgosedation makes it challenging to develop consensus guidelines and best practice recommendations.

\subsection{Pharmacokinetics and Pharmacodynamics in Critically Ill Children}

Pharmacokinetics (PK) and Pharmacodynamics (PD) are important when considering sedation and analgesia, particularly as the clearance, metabolism, and duration of effect can be impacted by end-organ (hepatic, renal, cardiac) failure and dysfunction $[15,16]$. The key factors that impact PK and PD in the PICU patient can be divided into two elements: Patient Factors and PICU Factors. Patient factors include body fluid shifts that impact drug volume of distribution; altered protein binding that can impact plasma concentration of drugs; end organ dysfunction that can alter drug absorption, metabolism, and excretion; natural age-related physiology that can impact drug absorption, metabolism, and excretion; and inflammatory states that alter drug-metabolizing enzymes and transporters and impact drug absorption, efficacy, and clearance [17-21]. PICU factors include non-pharmacologic interventions such as continuous renal replacement therapy (CRRT), extra-corporeal membrane oxygenation (ECMO), and therapeutic hypothermia, all of which affect volume of distribution, metabolism, absorption, and clearance [17-25].

Recent advancements in neonatal resuscitation combined with a significant decline in mortality introduce complex combinations of baseline multi-organ dysfunction which 
complicate the pharmacokinetic and pharmacodynamic profile of sedatives and analgesics in the PICU setting. As a result of the increasing complexity of interactions between the sedatives and the individual response, PICU sedation has evolved to encompass a special area of expertise $[15,21]$.

\section{Analgesia}

Effective and tailored acute, procedural, and chronic pain management is critical in the PICU. These conditions are often overlapping and require acute sensitivity to different components. The goal of analgesic therapy is to provide comfort, reduce physiological stress response, and minimize analgesic-associated adverse events such as respiratory depression, risk of addiction, hemodynamic instability, and end organ injury. In the severely critically ill pediatric patient, this balance is a delicate one that, if unsuccessful, can subject children to inadequate pain management $[15,26]$.

\subsection{Pain Assessment}

In order to titrate analgesic therapy to effect, manage pain adequately, and monitor for signs of medication toxicity or adverse effects, pain assessment is of utmost importance. Self-assessment to report pain scores, although considered the gold standard for monitoring the efficacy of analgesic therapy, is largely not possible for the majority of PICU patients [15,27]. Physiologic indicators (tachycardia, rise in blood pressure, tachypnea, pupillary dilatation, increased muscle tone, sweating, etc.) are equally unreliable markers as they lack sensitivity and specificity to pain. Pain-related behaviors, distinguished by verbal (vocalized description of intensity, quality, location with concomitant displays of moaning or crying) and non-verbal (facial expression, body posturing/repositioning, decrease in activity) cues have been shown to be similarly unreliable $[27,28]$.

In children $<3$ years of age, despite the limitations and challenges to assessing and interpreting the physiological indicators of pain and pain-related behaviors, behavioral observation scales are the standard of care. Subjective and objective indicators are used to interpret facial expression and physiologic and motor responses, frequently engaging the opinions of family members and primary caregivers [15,27]. Children ages 4 to 8 years are usually able to self-report pain, facilitating the practice of matching their subjective feedback to a developmentally appropriate pain tool [15,29-31]. Older children (8 years and above), are typically able to give a self-assessment of their pain using more validated methods such as a verbal rating scale, numeric rating scale (NRS), and the Visual analog Scale (VAS), similar to adults $[27,30]$. Not all pain scales require self-reporting and interpretation of verbal cues. The Wong-Baker FACES scale and the Bieri Faces Pain Scale Revised (FPS-R) are suitable for children of any age and developmental stage and rely on non-verbal cues [30]. Each scale has its limitations. The Neonatal Pain, Agitation, and Sedation Scale (N-PASS), Non-Verbal Pain Scale (NVPS), and the Face, Legs, Activity, Cry, and Consolability scale (FLACC) are observational scales that are unable to quantify the intensity or quality of pain. Regardless, especially for sedated and pharmacologically paralyzed PICU patients, these scales are a valuable means to identify the presence of pain $[30,32]$.

\subsection{Systemic Analgesia: Opiates and Non-Opiates}

\subsubsection{Opioids}

Opioids work on opiate receptors which are found in the brain, spinal cord, and peripheral tissue: $\mathrm{mu}(\mu)$ receptors (analgesia, euphoria, miosis, respiratory depression), kappa (k) receptors (spinal analgesia), sigma $(\sigma)$ (dysphoria, respiratory and vasomotor stimulation, and hallucinations), and delta $(\Delta)$ (unclear effects) [27,33,34]. All opioids exhibit a dose-dependent respiratory depression which increases in risk when given in conjunction with other sedatives, commonly benzodiazepines [34,35]. Due to the risk of dependence and withdrawal, opiates should be weaned slowly in those patients who have received opioid infusions $\geq 7$ days [33,34]. In general, in the PICU setting, opiates are favored for the relief of severe pain, especially perioperative and non-neuropathic. The 
Collaborative Pediatric Critical Care Research Network (CPCCRN) performed a prospective, observational study (the MOTIF (Measuring Opioid Tolerance Induced by Fentanyl (or morphine)) to characterize the exposure to opioid analgesia among mechanically ventilated children. Mechanically ventilated children required increasing opioid doses, often associated with prolonged opioid exposure or the need for additional sedation [36].

\section{Morphine}

Discovered over 200 years ago, morphine is the oldest of the opiates and the only hydrophilic opioid still in common use. A typical bolus dose of morphine achieves a peak effect in 10 to $20 \mathrm{~min}$ and has a duration of action of approximately $2-4 \mathrm{~h}[21,27]$. Morphine is metabolized by the liver via glucuronidation and its metabolites are then renally excreted $[37,38]$. The active metabolite of morphine, morphine-6-glucuronide $(10 \%)$, stimulates the mu-receptors, and it is recommended that especially in patients with renal insufficiency dosing of morphine should be carefully titrated or avoided altogether in order to avoid oversedation and respiratory depression [21,34,39-41]. Dosing of morphine must be done with consideration of the age, physiology, and medical condition of the child, as the pharmacokinetics of morphine differ from premature infants through childhood. Neonates $<10$ days old require less than half the dose of older children to attain similar plasma levels of morphine with similar analgesia [21,27,42]. Morphine, still the most commonly used sedative in the PICU, has important risks and side effects: vasodilation, hypotension, bronchospasm, and pruritus should be considered, however they are not usually clinically significant $[21,27,30,34,42]$.

\section{Fentanyl}

Fentanyl is a synthetic morphine derivative that is highly lipophilic and fat soluble, over 100 times more potent than morphine and exhibits very quick onset ( $<1$ to $2 \mathrm{~min}$ ) and up to 60-min duration with intermittent doses [27]. With continuous prolonged administration, fentanyl can accumulate in peripheral compartments, increasing the context sensitive half-life and prolonging sedation $[27,34]$. Unlike morphine, fentanyl has an inactive metabolite, norfentanyl, that does not cause histamine release. Be aware that because fentanyl depresses the heart rate response, it can have a negative effect on children who are heart rate dependent and rely on increased heart rate for augmentation of cardiac output. Conversely, fentanyl has its advantages, particularly for blunting heart rate response to intubation and laryngoscopy [43-47]. Although rare, there is a risk of chest wall rigidity, usually with rapid large ( $>5 \mathrm{mcg} / \mathrm{kg}$ ) doses, that can precipitate respiratory failure and necessitate intubation or naloxone $[5,21,48]$.

\section{Remifentanil}

Remifentanil is a newer synthetic opioid that is equipotent to fentanyl and has an ultrashort half-life of about 3 to $4 \mathrm{~min}$. Metabolized by plasma esterases, it does not accumulate and demonstrates a small volume of distribution [27]. Remifentanil is optimal for the patient with renal or hepatic dysfunction, as it avoids the risk of accumulation of active metabolites, and prolonged context sensitive half-life and duration of action. Remifentanil can facilitate the abrupt need to perform neurological exams, quickly wearing off even after prolonged infusions. This rapid onset and offset favors its use in the PICU setting, supporting rapid titration of analgesic and anesthetic depth with minimal fluctuations in hemodynamics [49]. Similar to other opioids, remifentanil does have respiratory and myocardial depressant effects that should be anticipated and managed appropriately. There has been concern that the ultra-short acting nature of remifentanil leads to an increased risk of rapid developmental of tolerance; also, it has been suggested that remifentanil has the highest association with opioid-induced hyperalgesia (OIH) amongst the opiates and $\mathrm{OIH}$ leads to prolonged post-operative recovery, increased length of stay, and significant discomfort [49,50]. The RAPIP trial (remifentanil-based analgesia and sedation of pediatric intensive care patients), a randomized controlled trial which aimed to compare remifentanil 
and fentanyl concerning the incidence of tolerance, withdrawal, and OIH, demonstrated no association between remifentanil and increased risk for tolerance, withdrawal or OIH [51].

\section{Hydromorphone}

Hydromorphone is a semi-synthetic opioid (a hydrogenated ketone of morphine) that selectively binds to the mu receptor [52]. Hydromorphone is hydrophilic and has 7 to 10 times the potency of morphine. Hydromorphone has an onset of 5 to $10 \mathrm{~min}$ and a duration of action of 3 to $4 \mathrm{~h}$, similar in profile to morphine's. Metabolized by hepatic glucuronidation to hydromorphone-3-glucuronide and excreted in the urine, hydromorphone is associated with less sedation, nausea, and pruritus than morphine [5,30,37,38]. Continuous infusions of hydromorphone have been shown to be effective for prolonged (greater than $24 \mathrm{~h}$ ) sedation in the PICU setting. With a mean starting dose of $0.024 \mathrm{mg} / \mathrm{kg} / \mathrm{h}$, and a maximum mean dose of $0.05 \mathrm{mg} / \mathrm{kg} / \mathrm{h}, 66 \%$ of mean daily FLACC scores were $<1$ in PICU patients sedated for a mean of $182 \mathrm{~h}$ [53].

\section{Methadone}

Methadone is a synthetic mu-receptor opioid agonist with rapid onset (5-10 min and 30-60 min via IV and oral route respectively). It has the longest duration of action of all the opioids (4 to $24 \mathrm{~h}$ ). Methadone's lack of known active metabolites, high oral bioavailability, and long duration of action supports its frequent choice to prevent opioid withdrawal for children who have received continuous morphine or fentanyl for $>5$ days [54-56]. Enteral administration of methadone has been shown to expedite opioid discontinuation and reduce the risk of withdrawal in critically ill children at very high risk for opioid abstinence syndrome [54-57].

The pharmacokinetic profile of methadone complicates an easy conversion to equipotent dose ratios between narcotics. There is still no consensus on an ideal conversion factor after prolonged IV fentanyl [54,58-60]. Methadone dose equivalents of 2.5 times the daily fentanyl dose have demonstrated success for weaning [48]. Applying standard adult dose conversion guidelines ( $23.7 \mathrm{mg}$ oral morphine to $1 \mathrm{mg}$ oral methadone) to the pediatric population, $53.7 \%$ of children in the PICU were successfully converted to methadone and $41.7 \%$ appeared undermedicated [61]. Regardless of the conversion formula applied, it is recommended that the Withdrawal Assessment Tool (WAT-1) and State Behavioral Scale be performed daily, to guide opioid weaning schedules [62,63].

Methadone carries a Food and Drug Administration (FDA) Boxed Warning due to its potential to prolong the corrected QT interval, potentially leading to life-threatening arrhythmias. A retrospective study of 51 PICU patients $<18$ years of age did not report an incidence of significant change of the corrected QT interval in this group. However, those that did manifest an increase in corrected QT interval of $\leq 40 \mathrm{~ms}$, had structural heart disease. Caution should therefore be taken when administering methadone to PICU patients with structural heart disease [64]. It is important to note that methadone is gaining notoriety in the media as the premier agent for medication-assisted treatment of opioid addiction. Parents will frequently raise concerns over its use.

\subsubsection{Patient-Controlled Analgesia (PCA) and Parent/Nursing-Controlled Analgesia (PNCA)}

PCA is a patient-controlled, on-demand, and intermittent means of administering sedatives and analgesics. PNCA is reserved for those patients who do not have the ability to control their self-administration. In these cases, the nurse or health care provider, often aided by the parent's input, assume responsibility for the dosing. The relationship between meperidine blood concentrations and minimum analgesic concentration of meperidine for post-operative analgesia was discovered and used as the pharmacologic basis of PCA $[65,66]$. Minimum effective analgesic concentration (MEAC) is defined as the smallest concentration at which pain is relieved. PCA has evolved to include patient-controlled epidural analgesia (PCEA) or Epidural PCA, peripheral nerve catheter PCA or patientcontrolled regional analgesia (PCRA), as well as a non-invasive method of transdermal 
PCA which delivers ionizable medications (fentanyl, for example) through the skin via iontophoresis and the application of an external electrical field [66,67].

Although the safety and efficacy of PCA for children has been well established and PCA for children is quite widely available [68,69], critically ill children as well as very young and/or intellectually disabled children may lack the appropriate cognitive function necessary for self-administration of analgesic medication. PCA by proxy via parent/nursingcontrolled analgesia (PNCA) can be effectively implemented through proper education of the proxy and careful monitoring for pain, side effects, and adverse events [70-73].

\subsubsection{Non-Opioids \\ Acetaminophen}

Acetaminophen is a synthetic, non-opiate, centrally acting analgesic and antipyretic derived from p-aminophenol $[74,75]$. Its high therapeutic index and efficacy to safety ratio makes it an attractive and widely used option for PICU mono and multimodal treatment of mild to severe pain as well as fever [74]. Acetaminophen does not affect platelet function or kidney function and is void of gastrointestinal, respiratory, or cardiovascular effects. The IV formulation of acetaminophen was approved for use in the United States in 2010 and has been in extensive use in over 80 countries since 2002 [75]. IV acetaminophen is especially advantageous in the PICU setting for those who have Nil Per Os (NPO) status or are intolerant of enteral feeds. IV acetaminophen achieves analgesic effects within $5 \mathrm{~min}$ of administration and reaches higher max concentration $\left(\mathrm{C}_{\max }\right)$ at an earlier time $\left(\mathrm{T}_{\max }\right)$ than the equivalent dosage administered by oral or rectal route [74,76-79]. Acetaminophen is metabolized by the liver via glucuronidation, oxidation, and sulfation. Regardless of route of administration, the terminal elimination half-life of acetaminophen is approximately 2 to $4 \mathrm{~h}$ in children, adolescents, and adults [74].

A limitation to the use of IV acetaminophen is often its high cost. In terms of cost per dose and total doses dispensed, IV acetaminophen ranks at the top of the list of most expensive medications used in the PICU, along with dexmedetomidine, eculizumab, and botulism immunoglobulin [80]. The use of IV acetaminophen in the ICU setting has been optimized through multidisciplinary quality improvement projects aimed at reducing the associated medication-related variable costs [80,81].

\section{Non-Steroidal Anti-Inflammatory Drugs (NSAIDs)}

NSAIDs work by blocking the production of prostaglandins which leads to the reduction of pain and inflammation. There are two types of NSAIDS: Non-Selective NSAIDs (ibuprofen, naproxen, ketorolac, and acetylsalicylic acid) that block two enzymes involved with inflammation-cyclooxygenase-1 (COX-1) and cyclooxygenase-2 (COX-2), and COX2 (celecoxib) Selective NSAIDs. Most commonly, only the non-selective NSAIDs are used in the PICU. The Cox enzymes catalyze the conversion of arachidonic acid into prostaglandin [82]. The COX-1 enzyme regulates key cellular processes of platelet aggregation, afferent arteriole vasodilation in the kidney, and acid protection of the gastric mucosa. The COX-2 enzyme is an inducible enzyme that increases during inflammatory processes and is present in the brain, kidney, bone, and female reproductive tract $[83,84]$. NSAIDs are widely used for their analgesic, anti-inflammatory, and antipyretic properties. Ibuprofen has become the NSAID of choice for enteral administration, favored for its efficacy and tolerability profile without the risk of Reye's Syndrome [85]. Ketorolac (IV and Oral), although not approved by the IV route for pediatric patients, is a frequent choice for post-operative analgesia in the PICU [71,86-88].

NSAIDs are favored for their lack of opiate-related side effects of nausea, vomiting, pruritus, respiratory depression, tolerance, withdrawal, sedation, and urinary retention [89]. Metabolized in the liver to inactive metabolites via oxidation and conjugation, NSAIDs are excreted in the urine [90]. The risks associated with NSAIDS are related to their inhibition of prostaglandin synthesis. Careful patient selection requires avoidance of its administration to those at risk of acute renal failure, post-surgical bleeding, or gastrointestinal toxicity. In 
the pediatric population, NSAIDS have not been shown to increase the risk of renal and bleeding complications for both cardiac and non-cardiac post-operative care [91].

\section{Gabapentin}

Though gabapentin is usually considered an antiepileptic, it is useful for opioidsparing pain management. Gabapentin inhibits presynaptic voltage-gated calcium channels (upregulated during surgical trauma) in the dorsal root ganglia and spinal cord, preventing release of excitatory neurotransmitters [92]. There is no well-established consensus on the appropriate dosing regimen for gabapentin in the pediatric population. In adults, administration every $2 \mathrm{~h}$ in the post-operative period has demonstrated effectiveness, especially for those at highest risk of severe pain $[92,93]$.

\section{Ketamine}

Ketamine is an $N$-methyl-D-aspartate (NMDA) antagonist which has been available since the mid-20th century. NMDA receptors have been shown to play an important role in central sensitization formation, so it makes sense that ketamine is an effective opioid adjunct [92]. Studies have demonstrated that low-dose ketamine use with standard opioid administration decreased opioid use and led to improved quality of pain, with no reported serious side effects especially in patients for whom higher postoperative pain scores were anticipated and patients with chronic pain and/or opioid dependency [92,94]. A retrospective study of 32 mechanically ventilated children reported that drug rotation with ketamine in mechanically ventilated children with opioid tolerance is feasible and seems to reduce the rate of fentanyl infusion [95].

\section{Alpha 2 Agonists}

The analgesic effect of alpha 2 agonists like dexmedetomidine and clonidine results from stimulation of $\alpha 2$-adrenoreceptors that are located both in the spinal cord and supraspinal region [92]. Adult studies have shown that both alpha 2 agonists reduce opioid consumption in the perioperative period with dexmedetomidine being more effective [96]. Clonidine is a potent analgesic adjuvant that improves the analgesic effects of anti-inflammatory agents and has significant antinociceptive effects when it is combined with opioids, ketamine, and local anesthetics [97]. Clonidine has been shown to be a highly effective analgesic agent in the perioperative period for adenotonsillectomy and ophthalmological surgery in children [98-100].

Dexmedetomidine has not been shown to reduce postoperative opioid requirements or pain scores in children. In combination with opioids, it has been shown to increase time to first analgesic, reduce the need for additional rescue analgesia doses and significantly lower rescue medication requirements for nausea and vomiting postoperatively [101,102]

\subsubsection{Multimodal Pain Management}

In the practice of pediatric pain management, a multimodal approach considering analgesics (opiate and non-opiate), local and regional analgesia is preferable to monotherapy. Ketamine, gabapentin, and alpha2 agonists have been shown to produce profound antinociceptive effects and reduce opioid use when combined with acetaminophen, NSAIDs, and opioids in both adult and pediatric literature $[21,92,103,104]$. Non-opioid analgesics have a ceiling effect when used alone. A combination of acetaminophen and NSAIDS have shown favorable results in decreasing opiate requirement and pain scores, avoiding the ceiling effect which can occur when each is utilized alone [103-106]. Multimodal analgesia has been demonstrated to be particularly effective in managing the pain associated with acute vasoocclusive crises in children and adults with sickle cell disease [107]. Continuous naloxone infusion is used in the PICU for treatment of opioid-induced pruritus. 


\subsection{Neuraxials and Peripheral Nerve Catheters}

Regional anesthesia, when used in combination with general anesthesia, has been shown to reduce the amount of opioids and inhaled anesthetics used intraoperatively $[103,108]$. The European prospective observational multicenter cohort study (APRICOT) prospectively collected data for over 31,000 pediatric procedures performed in 33 countries. Regional anesthesia was performed perioperatively for 4377 surgeries, with central and truncal blocks representing 43 and $42 \%$, respectively. Caudal blocks were the most common $(77 \%)$ central block [108]. Ultrasound guidance with proper training can decrease time to perform block, increase success rate, hasten onset time, prolong block duration, and decrease volume of local anesthetic required $[109,110]$. Continuous epidural anesthesia (CEA) (caudal, lumbar, and thoracic) is a common route of post-operative analgesia in the PICU. In the premature and term infants, CEA has been shown to decrease opiate requirements, duration and need for ventilatory support as well as duration of PICU stay [111-114]. Patient controlled epidural anesthesia (PCEA), popular in adults, is another option that has been used with success in older children and adolescents [103,115].

\section{Sedation}

Sedation in the PICU setting is especially challenging and poses issues that are unique. Mechanical ventilation presents the most significant challenge, balancing sedation to synchronize the patient's native work of breathing with that of the ventilator. The optimal condition for the non-neuromuscularly blocked patient would be that she is easily arousable or conscious, comfortable, and breathing in sync with the ventilator, a state that can be referred to as the Goldilocks Zone (not too deep and not too light) [21]. Balancing the depth of sedation is important because undersedation can lead to dislodged intravascular access and catheters, unplanned extubation and potentially staff or patient injury. Oversedation, on the other hand, can lead to unstable hemodynamics, respiratory depression and the potential for failure to extubate. Prolonged intubations pose an increased risk for muscle deconditioning, delirium, cognitive impairment, tolerance, withdrawal, and PICU-acquired complication (PACs) [1,6,21,116-120]. Naloxone and flumazenil boluses are used for reversal of unwanted opioid- and benzodiazepine-induced respiratory depression and oversedation.

\subsection{Sedation Assessment}

The State Behavioral Scale (SBS), the COMFORT scale, the COMFORT behavior scale (COMFORT-B scale), and the Richmond Agitation Sedation Scale (RASS) have been validated in PICU patients.

The SBS follows 8 behavioral dimensions in mechanically ventilated children: respiratory drive, response to ventilation, coughing, best response to stimulation, attentiveness to care provider, tolerance to care, consolability, and movement after being consoled [63]. Each behavioral marker can be assigned three-six levels, their sum intended to follow the patient along the sedation-agitation continuum. The SBS, intended for use along the entire pediatric age spectrum, purposely excluded descriptors which would not be met by children $<6$ years: ability to communicate, follow commands, and attempt to sit or climb out of bed [63]. Similarly, physiologic vital signs (heart rate, blood pressure, respiratory rate) were also excluded, as they have been shown to have low sensitivity and specificity for quantifying degree of sedation/agitation [63,121-123]. SBS score ranges from -3 (unresponsive) to +2 (agitated) with a target of 0 intended to achieve the "Goldilocks zone" of awake and able to calm. The SBS should be paired with pain assessment scores every $4 \mathrm{~h}$ as well as prior to any interventions that would alter the analgosedative level [63].

The COMFORT scale is an observational scale that measures eight clinical parameters to determine a critically ill child's level of distress. Unlike the SBS, the COMFORT scale contains two physiologic parameters and six behavioral dimensions: heart rate, mean arterial pressure, alertness, calmness, respiratory response, movement, muscle tone, facial expression. Heart rate and blood pressure, despite being reliable determinants and markers 
for sedation, have been shown to be of limited reliability and validity as determinants of the total COMFORT score [123]. The COMFORT-B scale eliminates these two physiologic parameters, identifying scores of $\leq 10$ as oversedation and $\geq 23$ as undersedation. A limitation of this scale, however, is that the scores of 10-23 are not predictive of adequate depth of sedation. Thus, the COMFORT-B scale is commonly used in conjunction with other observational scales, some requiring nursing input (Nurse Interpretation of Sedation Score) [21,124].

The RASS is an agitation and sedation scale which has been validated for both adults and children (intubated and non-intubated) in the critical care setting [125-127]. The RASS is a 10-point scale ranging from -5 (unresponsive) to +4 (combative) with 0 being alert and calm [125-127]. For neonates and children with cognitive or developmental limitations for whom level of arousal is difficult to assess, the original RASS has been adapted to replace eye contact with eye opening when the RASS is -1 to -3 [127].

An important limitation of all of these assessment scales is their inability to be used for children with neuromuscular blockade. For these patients, the Bispectral Index (BIS) monitor has been shown to correlate well with the COMFORT scores, particularly for those with deep sedation [128]. BIS should be considered for patients who are not able to mount a response, taking into account however that BIS values are vulnerable to inaccuracy related to some medications (ketamine, nitrous oxide), hemodynamics, electrical interference from other monitors, and temperature shifts [129].

\subsection{Sedatives}

\subsubsection{Benzodiazepines}

Benzodiazepines, particularly midazolam, are the most commonly used sedative in PICUs, used not only for sedation but also as muscle relaxants, anticonvulsants, amnestics, and hypnotics $[21,130]$. Benzodiazepines work on the on the gamma amino butyric acid (GABA)-A receptor, reducing the excitability of neurons thereby producing a calming effect on the brain $[131,132]$. Benzodiazepines demonstrate a dose-dependent respiratory and myocardial depressant effect and may cause hypotension, particularly in the hypovolemic neonate $[30,133,134]$.

\section{Midazolam}

Midazolam is a short acting benzodiazepine that is the sedative of choice in most PICUs $[30,130]$. Midazolam can be administered orally (PO), rectally (PR), intramuscularly (IM), intranasally (IN) and intravascularly (IV). Fastest onset is via the IV route at 1-3 min, followed by IM/IN at 5-10 $\mathrm{min}$ and then PO/PR at 10-30 min [5]. IV midazolam has a duration of action of 45 to $60 \mathrm{~min}$. When used for sedation, the IV bolus dose is 0.05 to $0.1 \mathrm{mg} / \mathrm{kg}$ (maximum of $20 \mathrm{mg}$ per dose) and the maintenance infusion ranges from 0.05 to $0.12 \mathrm{mg} / \mathrm{kg} / \mathrm{h}$. For refractory status epilepticus, a bolus of up to $0.2 \mathrm{mg} / \mathrm{kg}$ with a maintenance infusion up to $0.4 \mathrm{mg} / \mathrm{kg} / \mathrm{h}$ is common $[135,136]$. Midazolam is metabolized by hydroxylation to an active metabolite (1-OH midazolam) and subsequently undergoes glucuronidation to 1-OH-midazolam-glucuronide, also an active metabolite, which is then renally excreted. Patients with renal insufficiency or failure may experience oversedation with midazolam if there is no dose adjustment [137]. Adverse effects include tolerance, dependence, and withdrawal; there is also a risk of paradoxical hyperactivity when given as a bolus dose [116,117].

\section{Lorazepam}

Lorazepam is a long-acting benzodiazepine that is commonly used in the PICU for its antiepileptic and anxiolytic properties. Lorazepam can be administered PO, IM, and IV at the same dose of $0.5 \mathrm{mg} / \mathrm{kg}$ (maximum of $2 \mathrm{mg}$ per dose) [5,21]. IV lorazepam is dissolved in propylene glycol which at high levels can produce metabolic acidosis and renal dysfunction. Therefore, IV lorazepam is not used as an infusion $[21,138,139]$. Oral 
lorazepam plays an important role for converting and weaning patients from long term midazolam infusions to an oral regimen [21,140].

\section{Diazepam}

Diazepam is a long-acting benzodiazepine that is administered for its anxiolytic, muscle relaxant, and antiepileptic properties. It can be given PO or IV [5]. IV Diazepam is highly water insoluble and is dissolved in propylene glycol. Diazepam can burn on injection and may cause phlebitis with prolonged infusion. IV Diazepam has an onset of action of 4-5 min and a duration of action of 60 to $120 \mathrm{~min}$ [141]. Diazepam is metabolized in the liver-it is $\mathrm{N}$-demethylated by CYP3A4 and 2C19 to the active metabolite $\mathrm{N}$-desmethyldiazepam, and is hydroxylated by CYP3A4 to the active metabolite temazepam. N-desmethyldiazepam and temazepam are both further metabolized to oxazepam, and all are eliminated via glucuronidation. These metabolites are active, accumulate in renal failure, and lead to a half-life of diazepam which can range from 20 to $120 \mathrm{~h}[142,143]$.

\subsubsection{Barbiturates}

Barbiturates are useful for their antiepileptic properties and their ability to control intracranial hypertension. Similar to benzodiazepines, barbiturates act primarily via GABA agonism $[144,145]$. Respiratory depression and hypotension can occur with barbiturates and caution should be taken when weaning from prolonged infusions in order to avoid withdrawal.

\section{Sodium Thiopental}

Thiopental is short-acting and is used more commonly in the operating room for the induction of general anesthesia and in the pediatric critical care setting for neuro-protective intubations. Its peak onset is 1-2 $\mathrm{min}$ and the duration of action is $30 \mathrm{~min}$ [146]. The dose is age-dependent with infants requiring much higher induction doses of $5-8 \mathrm{mg} / \mathrm{kg}$ compared to children, teens and adults at $3-4 \mathrm{mg} / \mathrm{kg}[144,147,148]$. Thiopental is metabolized by hydroxylation and oxidation via hepatic metabolism and it has a long elimination half-life of up to $12 \mathrm{~h}[144,149]$. It is important to note that thiopental is no longer available in the US as its manufacturer embargoed its import to protest its use for death by lethal injection.

\section{Pentobarbital}

Pentobarbital is a long-acting barbiturate used for sedation, status epilepticus, and the treatment of refractory intracranial hypertension after severe traumatic brain injury. When administered via the IV route, pentobarbital has an onset of action at $5 \mathrm{~min}$, peaks at $15 \mathrm{~min}$ and has a duration of action $>6 \mathrm{~h}$. Pentobarbital undergoes hepatic metabolism via cytochrome p450-induced hydroxylation and glucuronidation [144]. Pentobarbital has an elimination half-life of 12-24 h [144]. Pentobarbital therapy can be effective for severe traumatic brain injury (TBI) of adults with refractory intracranial hypertension. A study of 55 patients reported a one-year survival at discharge of $40 \%$ with good functional outcomes in $68 \%$ of survivors at 1 year [144]. In pediatric patients with TBI, pentobarbital reduced ICP to below their treatment threshold of $20 \mathrm{~mm} \mathrm{hg}$ in $28 \%$ of patients within $6 \mathrm{~h}$. Side effects of myocardial depression with resultant hypotension, necessitating pressors, should be anticipated during treatment [150]. Pentobarbital is a valuable option for refractory intracranial hypertension not amenable to surgical intervention [151].

\subsubsection{Alpha Agonists}

Alpha agonists are often used alone or as adjuncts to sedative, opiates, or benzodiazepines [92]. The sedative-hypnotic effects of alpha 2 agonists are the result of inhibition of norepinephrine release from noradrenergic receptors in the locus ceruleus area of the brainstem [152]. The advantage of alpha 2 agonists is lack of respiratory depressant effect, advantageous in extubating children on prolonged sedatives [153-155]. Bradycardia, brad- 
yarrhythmia, and hypotension, not typically requiring pharmacologic intervention, should be anticipated $[154,156]$.

\section{Clonidine}

Clonidine can be delivered PO, IV, transdermally, or epidurally. Typical clonidine dose is 4 to $5 \mathrm{mcg} / \mathrm{kg}$. Clonidine IV bolus dose is 1 to $2 \mathrm{mcg} / \mathrm{kg}$ with $1 \mathrm{mcg} / \mathrm{kg} / \mathrm{hour}$ as an infusion rate. The dose for neuraxial Clonidine is $1-2 \mathrm{mcg} / \mathrm{kg}$. The transdermal patch delivers $0.1 \mathrm{mg}$ per $24 \mathrm{~h}$ and is changed weekly [157-161]. Fifty percent of a dose of clonidine is metabolized by the liver to inactive compounds while the other unchanged drug, along with the metabolites, is excreted in urine and stool. The elimination half-life of enteral clonidine is 12 to $16 \mathrm{~h}$; the CSF elimination half-life is $1.3 \mathrm{~h} \mathrm{[162].} \mathrm{Clonidine}$ and midazolam have comparable profiles for the sedation of ventilated children [156]. Clonidine has been used to wean children from prolonged dexmedetomidine and opiate infusions [163].

\section{Dexmedetomidine}

Dexmedetomidine is approved for administration only by the IV route but is effective also by the IM, IN, and sublingual route. It is metabolized by the liver via glucuronidation and oxidation and it has no active metabolites; the half-life of dexmedetomidine is $2 \mathrm{~h}[21,164]$. Dexmedetomidine's sedative effect closely mimics natural sleep, with EEG activity in children resembling Stage 2 sleep [165]. When comparing dexmedetomidine to midazolam and propofol in adults, dexmedetomidine improves arousability and patient cooperation, decreases duration of mechanical ventilation, and shortens time to extubation. Length of ICU stay and mortality rate were similar amongst the groups [15]. In children, dexmedetomidine is synergistic with propofol, decreasing propofol requirements by up to $50 \%$ when used for procedural sedation for gastrointestinal endoscopy [166]. An openlabel, pilot, prospective, multicenter, randomized controlled trial with dexmedetomidine was designed to evaluate the sedation of mechanically ventilated children. Dexmedetomidine as the primary sedative was feasible, appeared safe, achieved early, light sedation (State Behavioral Scale -1 to +1 ), and reduced midazolam requirements. There were more episodes of hypotension and bradycardia with the dexmedetomidine group (including one serious adverse event) but no difference in vasopressor requirements [167]. An observational prospective multicenter (9 PICUs) study (PROSDEX) evaluated the efficacy and effects of dexmedetomidine for prolonged sedation $(\geq 24 \mathrm{~h})$ in critically ill pediatric patients. Dexmedetomidine assured comfort, spared use of other sedatives, and attenuated withdrawal and delirium symptoms. The loading dose and infusion dosages of dexmedetomidine were independent risk factors for hemodynamic adverse events [168].

\subsubsection{Propofol}

Propofol is a GABA agonist and a diisopropyphenol anesthetic that is advantageous in the critical care setting due to its rapid onset (1-2 $\mathrm{min})$, high potency that consistently produces the desired sedative effect, short duration of action ( $2-8 \mathrm{~min})$, and antiemetic and euphoric properties that lead to more positive patient experience $[15,141,169]$. The bolus dose of propofol is 0.5 to $1 \mathrm{mg} / \mathrm{kg}$ with an infusion rate of 1 to $3 \mathrm{mg} / \mathrm{kg} / \mathrm{h}$. In general, the half-life of propofol after an infusion is 30 to $60 \mathrm{~min}$, longer with prolonged infusions as it is highly lipophilic, redistributed from fat stores $[15,141,169,170]$. Propofol is metabolized by hepatic glucuronidation and hydroxylation [169]. The adverse effects of propofol are pain on injection, vasodilation or negative inotropy leading to hypotension and/or bradycardia, respiratory depression, apnea, hypertriglyceridemia, and pancreatitis $[15,141,169,170]$. With prolonged infusion rates of $>4$ to $5 \mathrm{mg} / \mathrm{kg} / \mathrm{h}$ and use of long-term propofol infusion in pediatric patients, there is a risk of propofol infusion syndrome (PRIS) characterized by lactic acidemia, rhabdomyolysis, dysrhythmias, cardiac arrest, and a high mortality rate (52\% in children and $48 \%$ in adults) $[15,169,171]$. Despite the concern for PRIS, propofol is still widely used in PICUs [172-174]. 


\subsubsection{Ketamine}

Ketamine has both analgesic and sedative properties. Ketamine is a phencyclidine derivative and an NMDA antagonist and is typically used as an adjunctive sedative agent or as part of a multimodal analgesic regimen as discussed earlier $[30,94]$. Ketamine is rapidacting and it preserves laryngeal reflexes allowing for spontaneous respirations during procedural sedation. Ketamine is also a powerful bronchodilator which makes it the agent of choice in patients with severe bronchospasm like status asthmaticus [30]. Although ketamine is a myocardial depressant with vasodilating properties, its indirect sympathomimetic activity (stimulating catecholamine release and inhibition of catecholamine reuptake) preserves cardiac output and leads to increase in blood pressure and heart rate $[15,30]$.

Ketamine has a rapid onset of 30 to $60 \mathrm{~s}$ when given IV with effective procedural sedation conditions achieved in $1 \mathrm{~min}$ and lasting up to 5 to $10 \mathrm{~min}$. Adverse effects of ketamine include sialorrhea, as well as psychotogenic reactions such as emergence delirium, disorientation, hallucinations, and combativeness at higher serum concentrations [30,141,175-178]. Ketamine is metabolized by the liver to an active metabolite, norketamine; ketamine and norketamine are then further metabolized by the liver to water soluble compounds that are then renally excreted [179].

\subsubsection{Antihistamines and Antipsychotics in the PICU}

First generation (sedating) antihistamines such as promethazine, trimeprazine, and diphenhydramine have antidopaminergic and anticholinergic actions. These agents are non-specific and act on histaminic, serotonergic, and cholinergic receptors with marked central nervous system (CNS) effects such as hypnosis, sedation, antiemesis, and paradoxical excitation in children [21,180]. Although not commonly used for PICU sedation, they can be adjuncts for the management of acute agitation and delirium [21].

Antipsychotics (haloperidol, chlorpromazine, risperidone, olanzapine, and quetiapine) are useful treatments for refractory delirium [181]. First-generation antipsychotics, such as haloperidol and chlorpromazine, have high rates of extrapyramidal symptoms (EPS) due to their strong dopamine $\mathrm{D}_{2}$ antagonism [181]. Haloperidol is popular in the critical care setting because of its IV formulation. Second-generation antipsychotics such as risperidone, olanzapine, and quetiapine have lower rates of EPS and tardive dyskinesia but with long term use they are associated with an increased risk of weight gain, metabolic side effects, and dyslipidemia. Risperidone and quetiapine are often favored for their favorable side effect profile in the treatment of delirium [181-183].

\subsection{Sedation Protocols}

The efficacy of protocolized sedation is unclear in pediatrics due to the paucity of randomized, controlled clinical trials $[184,185]$. Sedation protocols for mechanically ventilated PICU patients have been shown to improve PICU resource utilization, decrease the benzodiazepine and opiate days and increase the amount of ventilated-time awake $[4,186]$. Nurse-implemented, goal-directed sedation protocols, however, have not been shown to decrease the days of mechanical ventilation. Figure 1 compares an updated and more appropriate analgosedation approach to a traditional benzodiazepine-based sedation regimen.

\subsection{Daily Sedation Interruption (DSI)}

Daily sedation interruption (DSI) has been used to mitigate the negative effects of oversedation and prolonged benzodiazepine use. A study comparing daily interruption versus continuous sedative infusions in mechanically ventilated children demonstrated that the length of mechanical ventilation, duration of intensive care unit stay, total dose of midazolam, and average calculated cost of the therapy were significantly reduced in the interrupted [187]. Conversely, a multicenter, randomized controlled trial comparing daily sedation interruption (DSI) plus protocolized sedation (DSI + PS) to protocolized sedation only (PS) found that interruption did not improve clinical outcome in critically 
ill children and was associated with increased mortality. The value of interrupted daily sedation still remains unclear. The differences in outcomes between these two groups could be attributed to differences in patient populations, medical conditions, and baseline ICU clinical practices $[21,188]$. These authors recommend, based on clinical experience, that should DSI be implemented, it be done with caution.

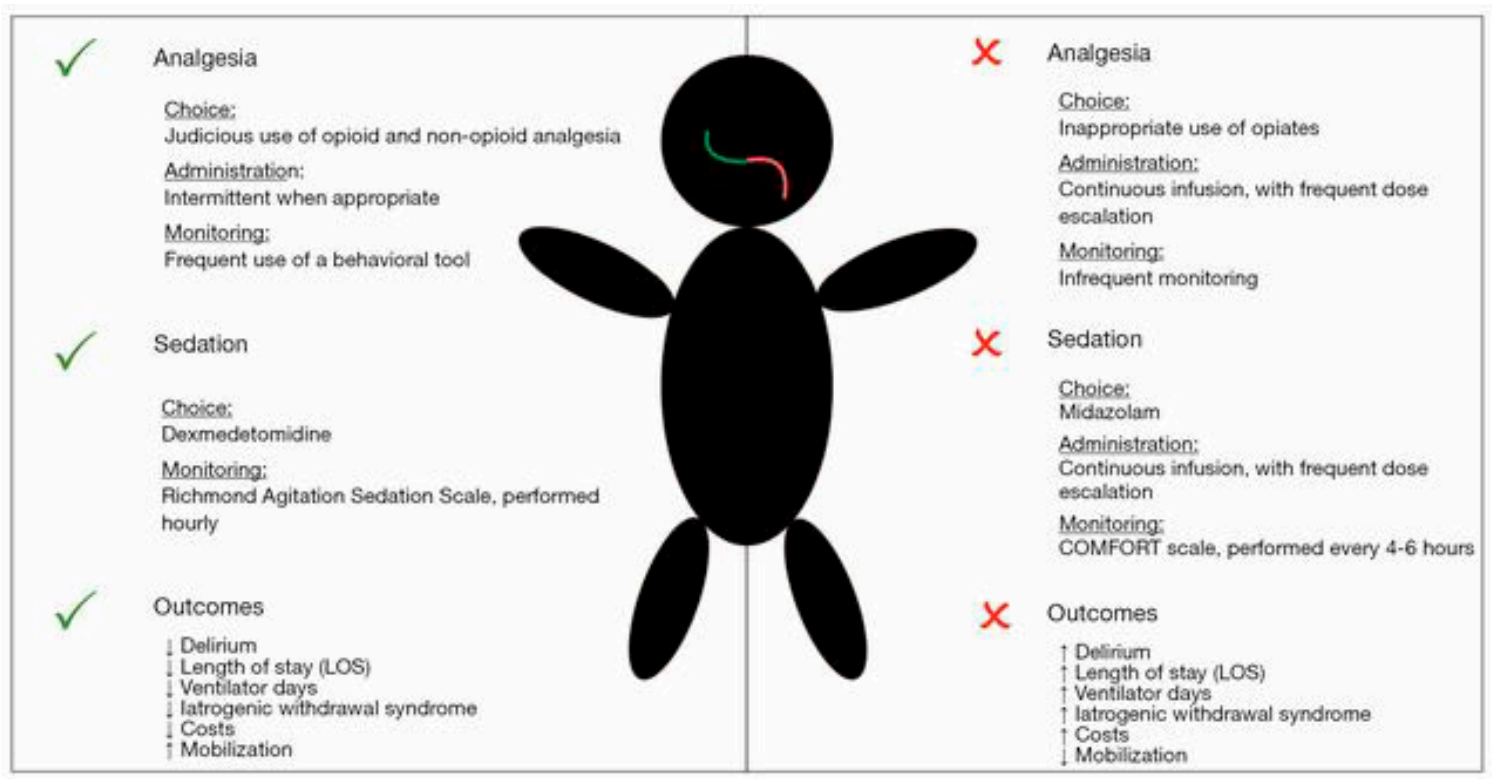

Figure 1. An updated analgosedation approach (left) versus a traditional benzodiazepine-based sedation regimen (right). Republished with permission of NANCY INTERNATIONAL LTD SUBSIDIARY AME PUBLISHING COMPANY, from Sedation strategies in children with pediatric acute respiratory distress syndrome (PARDS), Rosenberg, L. and Traube, C., Annals of Translational Medicine, Vol 7, No 19, 2019; permission conveyed through Copyright Clearance Center, Inc [185].

\subsection{Drug Cycling}

The rationale behind drug cycling is that cycling sedative agents will limit the patient tolerance and tachyphylaxis to the sedatives, decrease the body total deposit of sedatives, and subsequently decrease emergence time when the patient is ready for extubation. Some PICUs use drug cycling or drug rotating to decrease the adverse effects of continuous sedation, despite minimal data to support this practice $[21,189,190]$.

\subsection{Delirium in the PICU}

The American Psychiatric Association's fifth edition of the Diagnostic and Statistical Manual of Mental Disorders (DSM-5) define delirium as a disturbance in attention (i.e., reduced ability to direct, focus, sustain, and shift attention), awareness (reduced orientation to the environment), and cognition (e.g., memory deficit, disorientation, language, visuospatial ability) that develops over a short period of time (a few hours to a few days), tends to fluctuate in severity in the course of a day, is not better explained by a pre-existing, established, or evolving neurocognitive disorder, and there is evidence that the disturbance is a physiological consequence of another medical condition, substance intoxication, withdrawal syndrome, or multifactorial [191]. Delirium in the PICU leads to prolonged mechanical ventilation, increased length of PICU admission and hospital stay in general, higher rates of morbidity and mortality, and increased medical care cost [184-198]. Prolonged exposure to sedative medications, higher depths of sedation, young age, baseline developmental disorders, and PICU environmental factors are risk factors for delirium [185,192-194,199]. Diagnosing delirium can be especially challenging in the PICU setting as the symptoms of cognitive disturbance, hallucinations, and hypoactive delirium are not always able to be verbalized and expressed, especially in the young, preverbal, developmentally challenged patient $[21,200,201]$. 


\section{Delirium Monitoring and Treatment}

Risk factors associated with delirium may be reduced by decreasing medication exposure by measuring sedation depth, avoiding benzodiazepines and anticholinergics as much as possible, and protecting sleep by clustering patient cares, minimizing overhead pages, dimming lights at night, and using ear plugs and eye masks [130,202]. It is important to screen PICU patients regularly for delirium via validated assessment tools.

There are a variety of assessment tools. The Cornell Assessment of Pediatric Delirium (CAPD), considered the standard of care in most PICUs in North America, was validated in children of all ages for mechanically ventilated children $[9,185,203]$. The CAPD is $94 \%$ sensitive and 79\% specific [203]. A prospective observation double-blind cohort study to improve the specificity of the CAPD, to allow for accurate detection of delirium in developmentally delayed children admitted to the PICU, demonstrated that, when used in conjunction with RASS score fluctuation, the CAPD is a sensitive and specific tool for the detection of delirium in children with developmental delay and this allows for reliable delirium screening in this hard-to-assess population [204].

The Pediatric Confusion Assessment Method for the ICU (pCAM-ICU) for age five years and older and the Preschool Confusion Assessment Method (psCAM-ICU) are also validated in children and have high reliability, with a high sensitivity and specificity of $83 \%$ and 99\%, respectively [200]. The Sophia Observation withdrawal Symptoms scale-Pediatric Delirium scale (SOS-PD) is another validated tool for delirium screening in critically ill children, with measurement properties comparable to the CAPD, psCAM-ICU, and the pCAM-ICU and an overall sensitivity of $92.3 \%$ and specificity of $96.5 \%$ [205-207].

Treating delirium may involve non-pharmacologic and pharmacologic approaches. A retrospective matched cohort study in the PICU suggests that antipsychotics may be more effective for early vs late-onset delirium refractory to non-pharmacologic treatment [21,181]. Table 1 depicts a comparison of pediatric delirium screening tools [30].

Table 1. Comparison of Pediatric Delirium Screening Tools. Reprinted with permission from Beckman E. Analgesia and Sedation. In Buck ML, Manasco KB, eds. Pediatric Self-Assessment Program, 2017 Book 3. Sedation and Analgesia. Lenexa, KS: American College of Clinical Pharmacy, 2017 [30].

\begin{tabular}{|c|c|c|c|c|c|c|}
\hline & DRS-88 & DRS-R-98 & PAED & pCAM-ICU & psCAM-ICU & CAPD \\
\hline $\begin{array}{l}\text { PICU population } \\
\text { (n) }\end{array}$ & $\begin{array}{l}\text { Med/surg } \\
\text { (154) }\end{array}$ & $\begin{array}{l}\text { Med/surg } \\
\text { (154) }\end{array}$ & $\begin{array}{c}\text { Med/surg a } \\
\text { (154) }\end{array}$ & $\begin{array}{l}\text { Med/surg, } \\
\text { cardiac (68) }\end{array}$ & $\begin{array}{l}\text { Med/surg, } \\
\text { cardiac (300) }\end{array}$ & $\begin{array}{c}\text { General } \\
(111)\end{array}$ \\
\hline Age (year) & $1-17$ & $1-17$ & $1-17$ & $\geq 5$ & $0.5-5$ & Birth-21 year \\
\hline $\begin{array}{c}\text { Include mechanical } \\
\text { ventilation? }\end{array}$ & No & No & No & Yes & Yes & Yes \\
\hline Include developmental delay? & No & No & No & No & No & Yes \\
\hline Type of delirium & Hyperactive & Hyperactive & Hyperactive & $\begin{array}{l}\text { Hyperactive } \\
\text { Hypoactive }\end{array}$ & $\begin{array}{l}\text { Hyperactive } \\
\text { Hypoactive }\end{array}$ & $\begin{array}{l}\text { Hyperactive } \\
\text { Hypoactive }\end{array}$ \\
\hline No. of questions or domains & 10 & 16 & 5 & 4 & 4 & 8 \\
\hline Administering provider & Psychiatrist & Psychiatrist & Anesthesia & Bedside $^{b}$ & Bedside $b$ & Bedside $^{b}$ \\
\hline
\end{tabular}

\subsection{Withdrawal}

Prolonged infusions of analgosedative agents, especially opioids and benzodiazepines, leave patients at high risk of developing withdrawal with discontinuation.

A multidimensional predictive model identified younger age, preexisting cognitive or functional impairment, higher nursing workload, >one-to-one nurse staffing, $\geq 3$ preweaning sedative classes, higher preweaning mean daily opioid dose, higher sedative doses and longer exposure periods are risk factors for iatrogenic withdrawal syndrome in critically ill children [208].

Although opioid withdrawal syndrome can occur as early as two-three days, it tends to occur after five days of continuous opioid administration [209-211]. The most 
common symptoms of opioid withdrawal include diarrhea, vomit, sweat, and fever [209]. A mean benzodiazepine dose of $0.35 \mathrm{mg} / \mathrm{kg} / \mathrm{h}$ increases the risk of developing withdrawal symptoms which include anxiety, insomnia, irritability, restlessness, hand tremors, muscle spasms, and seizures [210,211]. The incidence of withdrawal after $>3$ days of infusions is cited as $37 \%$, with high benzodiazepine dosing as a predictor. Other studies report withdrawal in up to $50 \%$ after $48 \mathrm{~h}$, increasing to up to $80 \%$ after $>5$ days continuous infusion [211,212].

Withdrawal Monitoring and Treatment

Differentiating between delirium and withdrawal can be difficult using the current assessment tools which rely on clinical, physiologic, and behavioral signs [213]. Patients at high risk for withdrawal should be identified prior to initiating the infusion [209-211]. There are three validated iatrogenic withdrawal assessment scales specific for the pediatric population: Withdrawal Assessment Tool-1 (WAT-1) scale, the Opioid and Benzodiazepine Withdrawal Score (OBWS), and the Sophia Observation Withdrawal Symptoms (SOS) [212]. A major limitation of all these scales is their failure to accommodate for age and development. For example, the OBWS includes the Moro reflex which is a significant manifestation of withdrawal in newborns but disappears by three months of age. Future research needs to be directed to create new assessment tools or adapt these existing scales to developmental stages $[212,214]$.

Dexmedetomidine and clonidine have been shown to minimize the manifestations of iatrogenic withdrawal symptoms [212,215]. Enteral and parenteral methadone reduce the risk of iatrogenic withdrawal symptoms produced by opioids [57,212]. Phenobarbital has also been shown to be efficient in alleviating and reducing the intensity of refractory withdrawal from opioids and benzodiazepine [212]

\section{Neurodevelopmental Outcomes}

The majority of the studies assessing neurodevelopmental outcomes of pediatric patients exposed to analgosedative agents have focused mainly on general anesthesia. Brief $(<1 \mathrm{~h})$ exposure to general anesthesia has not been shown to alter neurodevelopmental outcome at age five years as compared to awake/regional anesthesia and general anesthesia exposure before age three years and is not associated with deficits in general intelligence [216,217]. Systematic review of studies evaluating neurodevelopmental outcomes and prospectively enrolling children exposed to a single GA procedure compared with unexposed children demonstrated that a single GA exposure is associated with statistically significant increases in parent reports of behavioral problems with, again, no difference in general intelligence [218]. Given key differences between general anesthesia and ICU sedation, such as the duration of exposure and the use of multimodal analgosedative regimen in the ICU, it is difficult to draw conclusions about PICU sedation from these general anesthesia studies.

Cumulative opioid dosing has shown an association with worse cognitive scores in extremely low birth weight NICU infants, even after adjusting for social and neonatal risk factors [219]. It is important to consider that the long-term neurocognitive outcomes of midazolam infusion for neonatal sedation in the intensive care unit is unclear and requires further study [220]. Another study failed to show an association between perioperative and post-operative anesthesia/sedation administration and neurodevelopmental outcomes up to two years following cardiac surgery [221]. A four year follow up of the same cohort demonstrated a small statistically significant association between days on chloral hydrate and Performance Intelligence Quotient (PIQ), and benzodiazepine cumulative dose and lower Beery-Buktenica Developmental Test of Visual Motor Integration (VMI-V). Despite these finding, there was no association between sedation/analgesia drugs and neurodevelopmental outcomes [222].

Adult ICUs have initiated care bundles to address neurocognitive patient outcomes. For example, each arm of the ABCDEF care bundle (Assess, prevent and manage pain; Both 
spontaneous awakening and breathing trials; Choice of sedative and analgesic; Delirium assessment, prevention, and management; Early mobilization and exercise; Family engagement and empowerment) helps prevent and decrease incidence of delirium and has been shown to enhance the rehabilitation potential of adult ICU patients [223]. Pediatric ICUs must continue to follow the adult model by actively working to adapt similar bundles to deliver well rounded patient care in order to optimize analgosedative regimens, engaging patients to participate in higher level physical and cognitive exercises [224].

\section{Early Mobilization}

Study data in critical care medicine suggest that survivors of both adult and pediatric critical illness tend to suffer significant physical, cognitive, and psychosocial morbidities that often lead to delayed recovery, poor rehabilitation, functional impairments, and decreased quality of life $[225,226]$. Early mobilization, a key aspect of the ICU Liberation ABCDEF bundle mentioned earlier, is gaining in popularity in critical care medicine, with PICUs taking the lead from adult ICUs. In the past, critically ill children were sedated and immobile because of concerns for their physiological fragility and risk of dislodging vital equipment; however, the ICU Liberation movement has led to a major cultural shift [224]. Large scale studies are still needed to accurately determine the outcomes of early mobilization in critically ill pediatric patients as the published data currently available reveal substantially variable outcome measures. Andelic et al., in their study to evaluate whether a continuous chain of rehabilitation that begins with the acute phase could improve the functional outcome of severe traumatic brain injury (TBI) patients, compared to a broken chain of rehabilitation that starts in the sub-acute phase of TBI, found that better functional outcome occurs in patients who receive an early onset and continuous chain of rehabilitation [227]. Jacobs et al. in their study to report the safety and efficacy of a postoperative approach that avoids pharmacologic and physical restraints, and allows liberal physical activity after single-stage laryngotracheal reconstruction in children, demonstrated that, for developmentally appropriate children, postoperative management after single-stage laryngotracheal reconstruction does not require the use of physical and pharmacologic restraints and that older children who are not sedated or restrained and who are allowed liberal physical activity have shorter pediatric intensive care unit and hospital lengths of stay, and a decreased incidence of postoperative adverse events [228].

Even though the data do suggest that early mobilization is safe, feasible, and can be employed in a variety of pediatric critically ill populations, implementing guidelines in the PICU can be quite challenging due to the vast differences in cognitive ability and physical capacity of pediatric patients, the scarcity of pediatric physiotherapy resources, and the great variability of medical diagnoses found in the PICU.

An observational quality improvement project called "PICU up!" studied 200 critically ill children to assess the feasibility of early mobility in the PICU, and demonstrated that implementation of a structured and stratified early mobilization program in the PICU was feasible and resulted in no adverse events. PICU Up! increased physical therapy and occupational therapy involvement in the children's care and increased early mobilization activities, including ambulation [229]. Simone et al., in their study, examined the impact of an ICU bundle on delirium screening and prevalence as well as described characteristics of delirium cases and found that implementation of an ICU bundle, along with staff education and case conferences, is effective for improving delirium screening, detection, and treatment and is associated with decreased delirium prevalence [207]. Family engagement is also crucial as some data suggest that family involvement helps propel early mobility efforts forward [227]. Bundled interventions that emphasize optimizing sedation such that frequent sedation assessment with validated tools helps guide the titration of analgosedative agents to goal-specific effects, minimizing benzodiazepines, screening for delirium frequently, and promoting sleep in the PICU will transform PICU culture of immobility and reduce the incidence of PICU-acquired complications (PACs). 


\section{Neuromuscular Blockade}

Neuromuscular blockade may be a necessary adjunct to analgosedative agents in patients who have serious to severe critical illness as it has been shown to help facilitate endotracheal intubation, prevent ventilator dyssynchrony, reduce barotrauma, facilitate mechanical ventilation in patients with high peak inspiratory pressures not responsive to conventional ventilation, decrease oxygen consumption in severe respiratory failure, minimize ventilator-induced lung injury (VILI), control intracranial pressure spikes in critical traumatic brain injury, control intraabdominal pressure spikes in patients with open abdomens post-operatively, and treat therapeutic hypothermia-induced shivering in post-cardiac arrest critical care $[15,230-235]$. Neuromuscular blocking agents (NMBAs) are selected based on indication, patient's comorbidities (hepatic or renal failure), and interactions with other drugs that may enhance or prolong their action [230]. Given the major concerns surrounding prolonged deep sedation and immobilization of patients in the PICU, neuromuscular blockade use in critical illness has decreased. There has been a concern for the development of critical illness myopathy (CIM), critical illness polyneuropathy (CIP), or the combination - critical illness polyneuromyopathy (CIPNM) with neuromuscular blockade and glucocorticoid administration in the ICU; however, most studies have shown no consistent relationship between critical illness neuromuscular abnormalities and the use of glucocorticoids and NMBAs [236]. Cisatracurium is more and more the agent of choice for maintenance of muscle relaxation in the PICU because it is a non-steroidal benzylisoquinoline that is broken down via Hoffman degradation independent of hepatic or renal metabolism or excretion and it has been shown to be associated with more rapid spontaneous recovery of neuromuscular function compared with vecuronium; however, there is no evidence that this observed difference in neuromuscular recovery affects outcomes $[237,238]$. It is also important to note that Cisatracurium is more expensive than all the other neuromuscular blocking agents. Regardless of the choice of muscle relaxant, the recommendation is to monitor the degree of neuromuscular blockade with regular clinical assessment (such as patient's spontaneous movements or triggering ventilator) and peripheral nerve stimulation using train of four or tetanic stimulation $[239,240]$. Also, neuromuscular blockade should be discontinued as quickly as safely possible in order to potentially decrease the incidence of prolonged recovery secondary to drug and metabolite accumulation and to potentially decrease the incidence of neuromuscular weakness related to critical illness [240].

\section{Conclusions}

A benchmark of successful sedation in PICU practice should target a situation in which a child is easily arousable or conscious, breathes in synchrony with a ventilator, tolerates procedures and general care routines, and generally appears comfortable. Optimal analgesia and sedation are dependent on the implementation of validated tools to guide the titration of analgosedative agents, and screen for withdrawal and delirium. Optimal sedation should minimize physical and chemical restraints, encourage safe liberal activity, promote restorative sleep, and reduce the incidence of PICU-acquired complications (PACs).

Author Contributions: Reviewing the relevant literature: C.E. and K.P.M.; Manuscript preparation: C.E. and K.P.M.; Approval of final manuscript and attestation to data integrity: C.E. and K.P.M. All authors have read and agreed to the published version of the manuscript.

Funding: This research received no external funding.

Acknowledgments: The authors acknowledge Kimberly Manning, BA, Department of Anesthesiology, Critical Care and Pain Medicine at Boston Children's Hospital, Boston, MA for her highly valued assistance in the preparation of this manuscript.

Conflicts of Interest: The authors declare no conflict of interest. 


\section{References}

1. Choong, K. PICU-acquired complications: The new marker of the quality of care. ICU Manag. Pract. 2019, 19, 85-88.

2. Burns, J.P.; Sellers, D.E.; Meyer, E.C.; Lewis-Newby, M.; Truog, R.D. Epidemiology of death in the PICU at five U.S. teaching hospitals*. Crit. Care Med. 2014, 42, 2101-2108. [CrossRef]

3. Doha, N.; El-Henawy, T.; Mohammed, M. Analgesia and sedation for patients in the intensive care unit: A systematic review. Menoufia Med. J. 2020, 33, 339-345. [CrossRef]

4. Curley, M.A.; Wypij, D.; Watson, R.S.; Grant, M.J.; Asaro, L.A.; Cheifetz, I.M.; Dodson, B.L.; Franck, L.S.; Gedeit, R.G.; Angus, D.C.; et al. Protocolized sedation vs. usual care in pediatric patients mechanically ventilated for acute respiratory failure: A randomized clinical trial. JAMA 2015, 313, 379-389. [CrossRef] [PubMed]

5. Barnes, S.; Yaster, M.; Kudchadkar, S.R. Pediatric sedation management. Pediatr. Rev. 2016, 37, 203-212. [CrossRef] [PubMed]

6. Hopkins, R.O.; Choong, K.; Zebuhr, C.A.; Kudchadkar, S.R. Transforming PICU culture to facilitate early rehabilitation. J. Pediatr. Intensive Care 2015, 4, 204-211. [CrossRef] [PubMed]

7. Playfor, S.; Jenkins, I.; Boyles, C.; Choonara, I.; Davies, G.; Haywood, T.; Hinson, G.; Mayer, A.; Morton, N.; Ralph, T.; et al. Consensus guidelines on sedation and analgesia in critically ill children. Intensive Care Med. 2006, 32, 1125-1136. [CrossRef]

8. Playfor, S.; Jenkins, I.; Boyles, C.; Choonara, I.; Davies, G.; Haywood, T.; Hinson, G.; Mayer, A.; Morton, N.; Ralph, T.; et al. Consensus guidelines for sustained neuromuscular blockade in critically ill children. Paediatr. Anaesth. 2007, 17, 881-887. [CrossRef] [PubMed]

9. Harris, J.; Ramelet, A.S.; van Dijk, M.; Pokorna, P.; Wielenga, J.; Tume, L.; Tibboel, D.; Ista, E. Clinical recommendations for pain, sedation, withdrawal and delirium assessment in critically ill infants and children: An ESPNIC position statement for healthcare professionals. Intensive Care Med. 2016, 42, 972-986. [CrossRef]

10. Patel, A.K.; Trujillo-Rivera, E.; Faruqe, F.; Heneghan, J.A.; Workman, T.E.; Zeng-Treitler, Q.; Chamberlain, J.; Morizono, H.; Kim, D.; Bost, J.E.; et al. Sedation, analgesia, and neuromuscular blockade: An assessment of practices from 2009 to 2016 in a national sample of 66,443 pediatric patients cared for in the ICU. Pediatr. Crit. Care Med. 2020, 21, e599-e609. [CrossRef]

11. Jenkins, I.A.; Playfor, S.D.; Bevan, C.; Davies, G.; Wolf, A.R. Current United Kingdom sedation practice in pediatric intensive care. Paediatr. Anaesth. 2007, 17, 675-683. [CrossRef]

12. Anand, K.J.; Willson, D.F.; Berger, J.; Harrison, R.; Meert, K.L.; Zimmerman, J.; Carcillo, J.; Newth, C.J.; Prodhan, P.; Dean, J.M.; et al. Tolerance and withdrawal from prolonged opioid use in critically ill children. Pediatrics 2010, 125, e1208-e1225. [CrossRef]

13. Mehta, S.; Burry, L.; Fischer, S.; Martinez-Motta, J.C.; Hallett, D.; Bowman, D.; Wong, C.; Meade, M.O.; Stewart, T.E.; Cook, D.J. Canadian survey of the use of sedatives, analgesics, and neuromuscular blocking agents in critically ill patients. Crit. Care Med. 2006, 34, 374-380. [CrossRef] [PubMed]

14. Matthews, A.J. An audit of sedation, analgesia and muscle relaxation in paediatric intensive care in the United Kingdom. Pediatr. Anesth. 1993, 3, 107-115. [CrossRef]

15. Hughes, C.G.; McGrane, S.; Pandharipande, P.P. Sedation in the intensive care setting. Clin. Pharmacol. 2012, 4, 53-63. [CrossRef] [PubMed]

16. Varghese, J.M.; Roberts, J.A.; Lipman, J. Pharmacokinetics and pharmacodynamics in critically ill patients. Curr. Opin. Anaesthesiol. 2010, 23, 472-478. [CrossRef]

17. Lu, H.; Rosenbaum, S. Developmental pharmacokinetics in pediatric populations. J. Pediatr. Pharmacol. Ther. 2014, 19, 262-276. [CrossRef]

18. Fernandez, E.; Perez, R.; Hernandez, A.; Tejada, P.; Arteta, M.; Ramos, J.T. Factors and mechanisms for pharmacokinetic differences between Pediatric population and adults. Pharmaceutics 2011, 3, 53-72. [CrossRef]

19. Dzierba, A.L.; Abrams, D.; Brodie, D. Medicating patients during extracorporeal membrane oxygenation: The evidence is building. Crit. Care 2017, 21, 66. [CrossRef]

20. Morgan, E.T. Impact of infectious and inflammatory disease on cytochrome P450-mediated drug metabolism and pharmacokinetics. Clin. Pharmacol. Ther. 2009, 85, 434-438. [CrossRef]

21. Vet, N.J.; Kleiber, N.; Ista, E.; de Hoog, M.; de Wildt, S.N. Sedation in Critically Ill Children with Respiratory Failure. Front. Pediatr. 2016, 4, 89. [CrossRef] [PubMed]

22. Mousavi, S.; Levcovich, B.; Mojtahedzadeh, M. A systematic review on pharmacokinetic changes in critically ill patients: Role of extracorporeal membrane oxygenation. Daru 2011, 19, 312-321. [PubMed]

23. Schetz, M. Drug dosing in continuous renal replacement therapy: General rules. Curr. Opin. Crit. Care 2007, 13, 645-651. [CrossRef]

24. Jang, S.M.; Infante, S.; Abdi Pour, A. Drug dosing considerations in critically ill patients receiving continuous renal replacement therapy. Pharmacy 2020, 8, 18. [CrossRef] [PubMed]

25. Zhou, J.; Poloyac, S.M. The effect of therapeutic hypothermia on drug metabolism and response: Cellular mechanisms to organ function. Expert Opin. Drug Metab. Toxicol. 2011, 7, 803-816. [CrossRef]

26. Jacobi, J.; Fraser, G.L.; Coursin, D.B.; Riker, R.R.; Fontaine, D.; Wittbrodt, E.T.; Chalfin, D.B.; Masica, M.F.; Bjerke, H.S.; Coplin, W.M.; et al. Clinical practice guidelines for the sustained use of sedatives and analgesics in the critically ill adult. Crit. Care Med. 2002, 30, 119-141. [CrossRef] [PubMed]

27. Playfor, S.D. Analgesia and sedation in critically ill children. Contin. Educ. Anaesth. Crit. Care Pain 2008, 8, 90-94. [CrossRef] 
28. Keefe, F.J.; Williams, D.A.; Smith, S.J. Assessment of pain behaviors. In Handbook of Pain Assessment, 2nd ed.; The Guilford Press: New York, NY, USA, 2001; pp. 170-187.

29. Freund, D.; Bolick, B.N. CE: Assessing a child's pain. Am. J. Nurs. 2019, 119, 34-41. [CrossRef]

30. Beckman, E.J. Analgesia and sedation in hospitalized children. In PedSAP 2017 Book 3: Sedation and Analgesia; The American College of Clinical Pharmacy: Lenexa, KS, USA, 2017; pp. 7-30.

31. McGrath, P.J.; Unruh, A.M. Measurement and assessment of pediatric pai. In Wall and Melzack's Textbook of Pain, 6th ed.; McMahon, S.B., Kolzenburg, M., Tracey, I., Turk, D., Eds.; Saunders: Philadelphia, PA, USA, 2013; pp. 320-327.

32. Wells, N.; Pasero, C.; McCaffery, M. Improving the quality of care through pain assessment and management. In Patient Safety and Quality: An Evidence-Based Handbook for Nurses; Hughes, R.G., Ed.; Agency for Healthcare Research and Quality (US): Rockville, MD, USA, 2008.

33. Devlin, J.W.; Skrobik, Y.; Gélinas, C.; Needham, D.M.; Slooter, A.J.C.; Pandharipande, P.P.; Watson, P.L.; Weinhouse, G.L.; Nunnally, M.E.; Rochwerg, B.; et al. Clinical practice guidelines for the prevention and management of pain, agitation/sedation, delirium, immobility, and sleep disruption in adult patients in the ICU. Crit. Care Med. 2018, 46, e825-e873. [CrossRef]

34. Gommers, D.; Bakker, J. Medications for analgesia and sedation in the intensive care unit: An overview. Crit. Care 2008, 12 (Suppl. 3), S4. [CrossRef]

35. Izrailtyan, I.; Qiu, J.; Overdyk, F.J.; Erslon, M.; Gan, T.J. Risk factors for cardiopulmonary and respiratory arrest in medical and surgical hospital patients on opioid analgesics and sedatives. PLoS ONE 2018, 13, e0194553. [CrossRef]

36. Anand, K.J.; Clark, A.E.; Willson, D.F.; Berger, J.; Meert, K.L.; Zimmerman, J.J.; Harrison, R.; Carcillo, J.A.; Newth, C.J.; Bisping, S.; et al. Opioid analgesia in mechanically ventilated children: Results from the multicenter measuring opioid tolerance induced by fentanyl study. Pediatr. Crit. Care Med. 2013, 14, 27-36. [CrossRef] [PubMed]

37. Smith, M.T. Neuroexcitatory effects of morphine and hydromorphone: Evidence implicating the 3-glucuronide metabolites. Clin. Exp. Pharmacol. Physiol. 2000, 27, 524-528. [CrossRef] [PubMed]

38. Due, M.R.; Piekarz, A.D.; Wilson, N.; Feldman, P.; Ripsch, M.S.; Chavez, S.; Yin, H.; Khanna, R.; White, F.A. Neuroexcitatory effects of morphine-3-glucuronide are dependent on Toll-like receptor 4 signaling. J. Neuroinflamm. 2012, 9, 200. [CrossRef] [PubMed]

39. Paul, D.; Standifer, K.M.; Inturrisi, C.E.; Pasternak, G.W. Pharmacological characterization of morphine-6 beta-glucuronide, a very potent morphine metabolite. J. Pharmacol. Exp. Ther. 1989, 251, 477-483.

40. Pasternak, G.W.; Bodnar, R.J.; Clark, J.A.; Inturrisi, C.E. Morphine-6-glucuronide, a potent mu agonist. Life Sci. 1987, 41, $2845-2849$. [CrossRef]

41. Francés, B.; Gout, R.; Campistron, G.; Panconi, E.; Cros, J. Morphine-6-glucuronide is more mu-selective and potent in analgesic tests than morphine. Prog. Clin. Biol. Res. 1990, 328, 477-480.

42. Krekels, E.H.; Tibboel, D.; de Wildt, S.N.; Ceelie, I.; Dahan, A.; van Dijk, M.; Danhof, M.; Knibbe, C.A. Evidence-based morphine dosing for postoperative neonates and infants. Clin. Pharmacokinet. 2014, 53, 553-563. [CrossRef]

43. Dahlgren, N.; Messeter, K. Treatment of stress response to laryngoscopy and intubation with fentanyl. Anaesthesia 1981, 36, 1022-1026. [CrossRef]

44. Martin, D.E.; Rosenberg, H.; Aukburg, S.J.; Bartkowski, R.R.; Edwards, M.W., Jr.; Greenhow, D.E.; Klineberg, P.L. Low-dose fentanyl blunts circulatory responses to tracheal intubation. Anesth. Analg. 1982, 61, 680-684. [CrossRef]

45. Kautto, U.M. Attenuation of the circulatory response to laryngoscopy and intubation by fentanyl. Acta Anaesthesiol. Scand. 1982, 26, 217-221. [CrossRef] [PubMed]

46. Ko, S.H.; Kim, D.C.; Han, Y.J.; Song, H.S. Small-dose fentanyl: Optimal time of injection for blunting the circulatory responses to tracheal intubation. Anesth. Analg. 1998, 86, 658-661. [CrossRef] [PubMed]

47. Xue, F.S.; Liu, K.P.; Liu, Y.; Xu, Y.C.; Liao, X.; Zhang, G.H.; Li, C.W.; Yang, Q.Y.; Sun, H.T. Assessment of small-dose fentanyl and sufentanil blunting the cardiovascular responses to laryngoscopy and intubation in children. Paediatr. Anaesth. 2007, 17, 568-574. [CrossRef]

48. Çoruh, B.; Tonelli, M.R.; Park, D.R. Fentanyl-induced chest wall rigidity. Chest 2013, 143, 1145-1146. [CrossRef] [PubMed]

49. Santonocito, C.; Noto, A.; Crimi, C.; Sanfilippo, F. Remifentanil-induced postoperative hyperalgesia: Current perspectives on mechanisms and therapeutic strategies. Local Reg. Anesth. 2018, 11, 15-23. [CrossRef]

50. Fletcher, D.; Martinez, V. Opioid-induced hyperalgesia in patients after surgery: A systematic review and a meta-analysis. Br. J. Anaesth. 2014, 112, 991-1004. [CrossRef]

51. Welzing, L.; Link, F.; Junghaenel, S.; Oberthuer, A.; Harnischmacher, U.; Stuetzer, H.; Roth, B. Remifentanil-induced tolerance, withdrawal or hyperalgesia in infants: A randomized controlled trial. RAPIP trial: Remifentanil-based analgesia and sedation of paediatric intensive care patients. Neonatology 2013, 104, 34-41. [CrossRef]

52. Quigley, C. Hydromorphone for acute and chronic pain. Cochrane Database Syst. Rev. 2002, Cd003447. [CrossRef]

53. Reiter, P.D.; Ng, J.; Dobyns, E.L. Continuous hydromorphone for pain and sedation in mechanically ventilated infants and children. J. Opioid Manag. 2012, 8, 99-104. [CrossRef]

54. Jeffries, S.A.; McGloin, R.; Pitfield, A.F.; Carr, R.R. Use of methadone for prevention of opioid withdrawal in critically ill children. Can. J. Hosp. Pharm. 2012, 65, 12-18. [CrossRef]

55. Lugo, R.A.; MacLaren, R.; Cash, J.; Pribble, C.G.; Vernon, D.D. Enteral methadone to expedite fentanyl discontinuation and prevent opioid abstinence syndrome in the PICU. Pharmacotherapy 2001, 21, 1566-1573. [CrossRef] 
56. Solodiuk, J.C.; Greco, C.D.; O’Donnell, K.A.; Morrill, D.R.; Curley, M.A.Q. Effect of a sedation weaning protocol on safety and medication use among hospitalized children post critical illness. J. Pediatr. Nurs. 2019, 49, 18-23. [CrossRef]

57. Siddappa, R.; Fletcher, J.E.; Heard, A.M.; Kielma, D.; Cimino, M.; Heard, C.M. Methadone dosage for prevention of opioid withdrawal in children. Paediatr. Anaesth. 2003, 13, 805-810. [CrossRef] [PubMed]

58. Gammaitoni, A.R.; Fine, P.; Alvarez, N.; McPherson, M.L.; Bergmark, S. Clinical application of opioid equianalgesic data. Clin. J. Pain 2003, 19, 286-297. [CrossRef]

59. Ripamonti, C.; Groff, L.; Brunelli, C.; Polastri, D.; Stavrakis, A.; De Conno, F. Switching from morphine to oral methadone in treating cancer pain: What is the equianalgesic dose ratio? J. Clin. Oncol. 1998, 16, 3216-3221. [CrossRef]

60. Anand, K.J.; Arnold, J.H. Opioid tolerance and dependence in infants and children. Crit. Care Med. 1994, 22, 334-342. [CrossRef] [PubMed]

61. Fife, A.; Postier, A.; Flood, A.; Friedrichsdorf, S.J. Methadone conversion in infants and children: Retrospective cohort study of 199 pediatric inpatients. J. Opioid Manag. 2016, 12, 123-130. [CrossRef]

62. Franck, L.S.; Harris, S.K.; Soetenga, D.J.; Amling, J.K.; Curley, M.A. The Withdrawal Assessment Tool-1 (WAT-1): An assessment instrument for monitoring opioid and benzodiazepine withdrawal symptoms in pediatric patients. Pediatr. Crit. Care Med. 2008, 9, 573-580. [CrossRef]

63. Curley, M.A.; Harris, S.K.; Fraser, K.A.; Johnson, R.A.; Arnold, J.H. State behavioral scale: A sedation assessment instrument for infants and young children supported on mechanical ventilation. Pediatr. Crit. Care Med. 2006, 7, 107-114. [CrossRef] [PubMed]

64. Friedman, S.D.; Kovach, J.R.; Thompson, N.E. Methadone's effect on cardiac repolarization: Safety in the PICU. Pediatr. Crit. Care Med. 2020, 21, e747-e751. [CrossRef] [PubMed]

65. Austin, K.L.; Stapleton, J.V.; Mather, L.E. Relationship between blood meperidine concentrations and analgesic response: A preliminary report. Anesthesiology 1980, 53, 460-466. [CrossRef]

66. Grass, J.A. Patient-controlled analgesia. Anesth. Analg. 2005, 101, S44-S61. [CrossRef] [PubMed]

67. Morlion, B.; Schäfer, M.; Betteridge, N.; Kalso, E. Non-invasive patient-controlled analgesia in the management of acute postoperative pain in the hospital setting. Curr. Med. Res. Opin. 2018, 34, 1179-1186. [CrossRef] [PubMed]

68. Berde, C.B.; Lehn, B.M.; Yee, J.D.; Sethna, N.F.; Russo, D. Patient-controlled analgesia in children and adolescents: A randomized, prospective comparison with intramuscular administration of morphine for postoperative analgesia. J. Pediatr. 1991, 118, 460-466. [CrossRef]

69. Nelson, K.L.; Yaster, M.; Kost-Byerly, S.; Monitto, C.L. A national survey of American Pediatric Anesthesiologists: Patientcontrolled analgesia and other intravenous opioid therapies in pediatric acute pain management. Anesth. Analg. 2010, 110, 754-760. [CrossRef]

70. Anghelescu, D.L.; Burgoyne, L.L.; Oakes, L.L.; Wallace, D.A. The safety of patient-controlled analgesia by proxy in pediatric oncology patients. Anesth. Analg. 2005, 101, 1623-1627. [CrossRef]

71. Voepel-Lewis, T.; Marinkovic, A.; Kostrzewa, A.; Tait, A.R.; Malviya, S. The prevalence of and risk factors for adverse events in children receiving patient-controlled analgesia by proxy or patient-controlled analgesia after surgery. Anesth. Analg. 2008, 107, 70-75. [CrossRef]

72. Czarnecki, M.L.; Salamon, K.S.; Jastrowski Mano, K.E.; Ferrise, A.S.; Sharp, M.; Weisman, S.J. A preliminary report of parent/nurse-controlled analgesia (PNCA) in infants and preschoolers. Clin. J. Pain 2011, 27, 102-107. [CrossRef]

73. Anghelescu, D.L.; Faughnan, L.G.; Oakes, L.L.; Windsor, K.B.; Pei, D.; Burgoyne, L.L. Parent-controlled PCA for pain management in pediatric oncology: Is it safe? J. Pediatr. Hematol. Oncol. 2012, 34, 416-420. [CrossRef] [PubMed]

74. Jahr, J.S.; Lee, V.K. Intravenous acetaminophen. Anesthesiol. Clin. 2010, 28, 619-645. [CrossRef]

75. Nishimoto, R.N. OFIRMEV: An old drug becomes new again. Anesth. Prog. 2014, 61, 99-102. [CrossRef]

76. Bertolini, A.; Ferrari, A.; Ottani, A.; Guerzoni, S.; Tacchi, R.; Leone, S. Paracetamol: New vistas of an old drug. CNS Drug Rev. 2006, 12, 250-275. [CrossRef]

77. Malaise, O.; Bruyere, O.; Reginster, J.-Y. Intravenous paracetamol: A review of efficacy and safety in therapeutic use. Future Neurol. 2007, 2, 673-688. [CrossRef]

78. Jarde, O.; Boccard, E. Parenteral versus oral route increases paracetamol efficacy. Clin. Drug Investig. 1997, 14, 474-481. [CrossRef]

79. Holmér Pettersson, P.; Owall, A.; Jakobsson, J. Early bioavailability of paracetamol after oral or intravenous administration. Acta Anaesthesiol. Scand. 2004, 48, 867-870. [CrossRef] [PubMed]

80. Howell, K.A.; Ruggles, C.A.; Thompson, M.; Metzger, K.Z.; Christopher, J.A.; Bigham, M.T. Using quality improvement to reduce IV Acetaminophen use in a PICU. Pediatr. Crit. Care Med. 2020, 21, 550-556. [CrossRef]

81. Vincent, W.R., 3rd; Huiras, P.; Empfield, J.; Horbowicz, K.J.; Lewis, K.; McAneny, D.; Twitchell, D. Controlling postoperative use of i.v. acetaminophen at an academic medical center. Am. J. Health Syst. Pharm. 2018, 75, 548-555. [CrossRef]

82. Vane, J.R. Inhibition of prostaglandin synthesis as a mechanism of action for aspirin-like drugs. Nat. New Biol. 1971, 231, 232-235. [CrossRef] [PubMed]

83. Adelizzi, R.A. COX-1 and COX-2 in health and disease. J. Am. Osteopath. Assoc. 1999, 99, S7-S12. [CrossRef]

84. Dubois, R.N.; Abramson, S.B.; Crofford, L.; Gupta, R.A.; Simon, L.S.; Van De Putte, L.B.; Lipsky, P.E. Cyclooxygenase in biology and disease. FASEB J. 1998, 12, 1063-1073. [CrossRef]

85. de Martino, M.; Chiarugi, A.; Boner, A.; Montini, G.; De'Angelis, G.L. Working towards an appropriate use of ibuprofen in children: An evidence-based appraisal. Drugs 2017, 77, 1295-1311. [CrossRef] 
86. McNicol, E.D.; Rowe, E.; Cooper, T.E. Ketorolac for postoperative pain in children. Cochrane Database Syst. Rev. 2018, 7, Cd012294. [CrossRef] [PubMed]

87. Cohen, M.N.; Christians, U.; Henthorn, T.; Vu Tran, Z.; Moll, V.; Zuk, J.; Galinkin, J. Pharmacokinetics of single-dose intravenous ketorolac in infants aged 2-11 months. Anesth. Analg. 2011, 112, 655-660. [CrossRef]

88. Jitpakdee, T.; Mandee, S. Strategies for preventing side effects of systemic opioid in postoperative pediatric patients. Paediatr. Anaesth. 2014, 24, 561-568. [CrossRef] [PubMed]

89. Forrest, J.B.; Heitlinger, E.L.; Revell, S. Ketorolac for postoperative pain management in children. Drug Saf. 1997, 16, 309-329. [CrossRef]

90. Mazaleuskaya, L.L.; Theken, K.N.; Gong, L.; Thorn, C.F.; FitzGerald, G.A.; Altman, R.B.; Klein, T.E. PharmGKB summary: Ibuprofen pathways. Pharm. Genom. 2015, 25, 96-106. [CrossRef] [PubMed]

91. Gaid, E.; Mehta, R.; Waller, J. The routine use of post-operative NSAIDs in the pediatric patient is effective and safe. Pediatrics 2020, 146, 165-166. [CrossRef]

92. Kaye, A.D.; Urman, R.D.; Rappaport, Y.; Siddaiah, H.; Cornett, E.M.; Belani, K.; Salinas, O.J.; Fox, C.J. Multimodal analgesia as an essential part of enhanced recovery protocols in the ambulatory settings. J. Anaesthesiol. Clin. Pharmacol. 2019, 35, S40-S45. [CrossRef]

93. Tiippana, E.M.; Hamunen, K.; Kontinen, V.K.; Kalso, E. Do surgical patients benefit from perioperative gabapentin/pregabalin? A systematic review of efficacy and safety. Anesth. Analg. 2007, 104, 1545-1556. [CrossRef]

94. Laskowski, K.; Stirling, A.; McKay, W.P.; Lim, H.J. A systematic review of intravenous ketamine for postoperative analgesia. Can. J. Anaesth. 2011, 58, 911-923. [CrossRef]

95. Neunhoeffer, F.; Hanser, A.; Esslinger, M.; Icheva, V.; Kumpf, M.; Gerbig, I.; Hofbeck, M.; Michel, J. Ketamine infusion as a counter measure for opioid tolerance in mechanically ventilated children: A pilot study. Paediatr. Drugs 2017, 19, 259-265. [CrossRef] [PubMed]

96. Blaudszun, G.; Lysakowski, C.; Elia, N.; Tramèr, M.R. Effect of perioperative systemic $\alpha 2$ agonists on postoperative morphine consumption and pain intensity: Systematic review and meta-analysis of randomized controlled trials. Anesthesiology 2012, 116, 1312-1322. [CrossRef]

97. Tryba, M.; Gehling, M. Clonidine-A potent analgesic adjuvant. Curr. Opin. Anaesthesiol. 2002, 15, 511-517. [CrossRef]

98. Basker, S.; Singh, G.; Jacob, R. Clonidine in paediatrics-A review. Indian J. Anaesth. 2009, 53, $270-280$.

99. Reimer, E.J.; Dunn, G.S.; Montgomery, C.J.; Sanderson, P.M.; Scheepers, L.D.; Merrick, P.M. The effectiveness of clonidine as an analgesic in paediatric adenotonsillectomy. Can. J. Anaesth. 1998, 45, 1162-1167. [CrossRef]

100. Nishina, K.; Mikawa, K.; Shiga, M.; Takao, Y.; Maekawa, N.; Obara, H. Diclofenac and flurbiprofen with or without clonidine for postoperative analgesia in children undergoing elective ophthalmological surgery. Paediatr. Anaesth. 2000, 10, 645-651. [CrossRef]

101. Reddy, S.K.; Jones, J.J.; Gordish-Dressman, H.; Pestieau, S.R. Dexmedetomidine as an opioid-sparing agent in pediatric craniofacial surgery. Children 2020, 7, 68. [CrossRef] [PubMed]

102. Olutoye, O.A.; Glover, C.D.; Diefenderfer, J.W.; McGilberry, M.; Wyatt, M.M.; Larrier, D.R.; Friedman, E.M.; Watcha, M.F. The effect of intraoperative dexmedetomidine on postoperative analgesia and sedation in pediatric patients undergoing tonsillectomy and adenoidectomy. Anesth. Analg. 2010, 111, 490-495. [CrossRef] [PubMed]

103. Verghese, S.T.; Hannallah, R.S. Acute pain management in children. J. Pain Res. 2010, 3, 105-123. [CrossRef]

104. Jin, F.; Chung, F. Multimodal analgesia for postoperative pain control. J. Clin. Anesth. 2001, 13, 524-539. [CrossRef]

105. Hong, J.Y.; Won Han, S.; Kim, W.O.; Kil, H.K. Fentanyl sparing effects of combined ketorolac and acetaminophen for outpatient inguinal hernia repair in children. J. Urol. 2010, 183, 1551-1555. [CrossRef]

106. Ong, C.K.; Seymour, R.A.; Lirk, P.; Merry, A.F. Combining paracetamol (acetaminophen) with nonsteroidal antiinflammatory drugs: A qualitative systematic review of analgesic efficacy for acute postoperative pain. Anesth. Analg. 2010, 110, 1170-1179. [CrossRef]

107. Uwaezuoke, S.N.; Ayuk, A.C.; Ndu, I.K.; Eneh, C.I.; Mbanefo, N.R.; Ezenwosu, O.U. Vaso-occlusive crisis in sickle cell disease: Current paradigm on pain management. J. Pain Res. 2018, 11, 3141-3150. [CrossRef] [PubMed]

108. Dadure, C.; Veyckemans, F.; Bringuier, S.; Habre, W. Epidemiology of regional anesthesia in children: Lessons learned from the European Multi-Institutional Study APRICOT. Paediatr. Anaesth. 2019, 29, 1128-1135. [CrossRef] [PubMed]

109. Ivani, G.; Mosseti, V. Pediatric regional anesthesia. Minerva Anestesiol. 2009, 75, 577-583.

110. Walker, B.J.; Long, J.B.; De Oliveira, G.S.; Szmuk, P.; Setiawan, C.; Polaner, D.M.; Suresh, S. Peripheral nerve catheters in children: An analysis of safety and practice patterns from the pediatric regional anesthesia network (PRAN). Br. J. Anaesth. 2015, 115, 457-462. [CrossRef] [PubMed]

111. De Pinto, M.; Dagal, A.; O’Donnell, B.; Stogicza, A.; Chiu, S.; Edwards, W.T. Regional anesthesia for management of acute pain in the intensive care unit. Int. J. Crit. Illn. Inj. Sci. 2015, 5, 138-143. [CrossRef]

112. Yuki, K.; Matsunami, E.; Tazawa, K.; Wang, W.; DiNardo, J.A.; Koutsogiannaki, S. Pediatric perioperative stress responses and anesthesia. Transl. Perioper. Pain Med. 2017, 2, 1-12.

113. Wolf, A.R. Effects of regional analgesia on stress responses to pediatric surgery. Paediatr. Anaesth. 2012, 22, 19-24. [CrossRef]

114. Craven, P.D.; Badawi, N.; Henderson-Smart, D.J.; O'Brien, M. Regional (spinal, epidural, caudal) versus general anaesthesia in preterm infants undergoing inguinal herniorrhaphy in early infancy. Cochrane Database Syst. Rev. 2003, Cd003669. [CrossRef] 
115. Arms, D.M.; Smith, J.T.; Osteyee, J.; Gartrell, A. Postoperative epidural analgesia for pediatric spine surgery. Orthopedics 1998, 21, 539-544. [PubMed]

116. Fonsmark, L.; Rasmussen, Y.H.; Carl, P. Occurrence of withdrawal in critically ill sedated children. Crit. Care Med. 1999, 27, 196-199. [CrossRef] [PubMed]

117. Ista, E.; van Dijk, M.; Gamel, C.; Tibboel, D.; de Hoog, M. Withdrawal symptoms in critically ill children after long-term administration of sedatives and/or analgesics: A first evaluation. Crit. Care Med. 2008, 36, 2427-2432. [CrossRef] [PubMed]

118. Garcia Guerra, G.; Joffe, A.R.; Cave, D.; Duff, J.; Duncan, S.; Sheppard, C.; Tawfik, G.; Hartling, L.; Jou, H.; Vohra, S. Survey of sedation and analgesia practice among canadian pediatric critical care physicians. Pediatr. Crit. Care Med. 2016, 17, 823-830. [CrossRef]

119. Cunningham, M.E.; Vogel, A.M. Analgesia, sedation, and delirium in pediatric surgical critical care. Semin. Pediatr. Surg. 2019, 28, 33-42. [CrossRef]

120. Saliski, M.; Kudchadkar, S.R. Optimizing Sedation management to promote early mobilization for critically ill children. J. Pediatr. Intensive Care 2015, 4, 188-193. [CrossRef]

121. Ambuel, B.; Hamlett, K.W.; Marx, C.M.; Blumer, J.L. Assessing distress in pediatric intensive care environments: The COMFORT scale. J. Pediatr. Psychol. 1992, 17, 95-109. [CrossRef]

122. Curley, M.; McDermott, B.; Berry, P.; Hurley, J.; MacKey, C.; McAleer, D.; Alsip, C. Nurses' decision making regarding the use of sedatives and analgesics in pediatric ICU. Heart Lung 1992, 21, 296.

123. Carnevale, F.A.; Razack, S. An item analysis of the COMFORT scale in a pediatric intensive care unit. Pediatr. Crit. Care Med. 2002, 3, 177-180. [CrossRef] [PubMed]

124. Ista, E.; van Dijk, M.; Tibboel, D.; de Hoog, M. Assessment of sedation levels in pediatric intensive care patients can be improved by using the COMFORT "behavior" scale. Pediatr. Crit. Care Med. 2005, 6, 58-63. [CrossRef] [PubMed]

125. Sessler, C.N.; Gosnell, M.S.; Grap, M.J.; Brophy, G.M.; O’Neal, P.V.; Keane, K.A.; Tesoro, E.P.; Elswick, R.K. The richmond agitation-sedation scale: Validity and reliability in adult intensive care unit patients. Am. J. Respir. Crit. Care Med. 2002, 166, 1338-1344. [CrossRef] [PubMed]

126. Kerson, A.G.; DeMaria, R.; Mauer, E.; Joyce, C.; Gerber, L.M.; Greenwald, B.M.; Silver, G.; Traube, C. Validity of the Richmond Agitation-Sedation Scale (RASS) in critically ill children. J. Intensive Care 2016, 4, 65. [CrossRef] [PubMed]

127. Kihlstrom, M.J.; Edge, A.P.; Cherry, K.M.; Zarick, P.J.; Beck, S.D.; Boyd, J.M. Multi-modal educational curriculum to improve richmond agitation-sedation scale inter-rater reliability in pediatric patients. Pediatr. Qual. Saf. 2018, 3, e096. [CrossRef]

128. Triltsch, A.E.; Nestmann, G.; Orawa, H.; Moshirzadeh, M.; Sander, M.; Grosse, J.; Genähr, A.; Konertz, W.; Spies, C.D. Bispectral index versus COMFORT score to determine the level of sedation in paediatric intensive care unit patients: A prospective study. Crit. Care 2005, 9, R9-R17. [CrossRef] [PubMed]

129. Playfor, S.D. The use of bispectral index monitors in paediatric intensive care. Crit. Care 2005, 9, 25-26. [CrossRef]

130. Kudchadkar, S.R.; Yaster, M.; Punjabi, N.M. Sedation, sleep promotion, and delirium screening practices in the care of mechanically ventilated children: A wake-up call for the pediatric critical care community*. Crit. Care Med. 2014, 42, 1592-1600. [CrossRef]

131. Fox, C.; Liu, H.; Kaye, A. Antianxiety Agents. In Clinical Aspects of Pain Medicine and Interventional Pain Management: A Comprehensive Review; ASIP Publishing: Paducah, KY, USA, 2011; pp. 543-552.

132. Griffin, C.E., 3rd; Kaye, A.M.; Bueno, F.R.; Kaye, A.D. Benzodiazepine pharmacology and central nervous system-mediated effects. Ochsner J. 2013, 13, 214-223.

133. Mihic, S.J.; Harris, R.A. Hypnotics and sedatives. In Goodman E Gilman's Pharmacological Basis of Therapeutics, 12th ed.; Goodman, L.S., Brunton, L.L., Chabner, B., Knollmann, B.C., Eds.; McGraw-Hill: New York, NY, USA, 2011.

134. Anand, K.J.; Hall, R.W.; Desai, N.; Shephard, B.; Bergqvist, L.L.; Young, T.E.; Boyle, E.M.; Carbajal, R.; Bhutani, V.K.; Moore, M.B.; et al. Effects of morphine analgesia in ventilated preterm neonates: Primary outcomes from the NEOPAIN randomised trial. Lancet 2004, 363, 1673-1682. [CrossRef]

135. Boylan, G.B.; Rennie, J.M.; Chorley, G.; Pressler, R.M.; Fox, G.F.; Farrer, K.; Morton, M.; Binnie, C.D. Second-line anticonvulsant treatment of neonatal seizures: A video-EEG monitoring study. Neurology 2004, 62, 486-488. [CrossRef]

136. Castro Conde, J.R.; Hernández Borges, A.A.; Doménech Martínez, E.; González Campo, C.; Perera Soler, R. Midazolam in neonatal seizures with no response to phenobarbital. Neurology 2005, 64, 876-879. [CrossRef]

137. Bauer, T.M.; Ritz, R.; Haberthür, C.; Ha, H.R.; Hunkeler, W.; Sleight, A.J.; Scollo-Lavizzari, G.; Haefeli, W.E. Prolonged sedation due to accumulation of conjugated metabolites of midazolam. Lancet 1995, 346, 145-147. [CrossRef]

138. Yahwak, J.A.; Riker, R.R.; Fraser, G.L.; Subak-Sharpe, S. Determination of a lorazepam dose threshold for using the osmol gap to monitor for propylene glycol toxicity. Pharmacotherapy 2008, 28, 984-991. [CrossRef] [PubMed]

139. Chicella, M.; Jansen, P.; Parthiban, A.; Marlowe, K.F.; Bencsath, F.A.; Krueger, K.P.; Boerth, R. Propylene glycol accumulation associated with continuous infusion of lorazepam in pediatric intensive care patients. Crit. Care Med. 2002, 30, 2752-2756. [CrossRef] [PubMed]

140. van der Vossen, A.C.; van Nuland, M.; Ista, E.G.; de Wildt, S.N.; Hanff, L.M. Oral lorazepam can be substituted for intravenous midazolam when weaning paediatric intensive care patients off sedation. Acta Paediatr. 2018, 107, 1594-1600. [CrossRef] [PubMed]

141. Krauss, B.; Green, S.M. Procedural sedation and analgesia in children. Lancet 2006, 367, 766-780. [CrossRef]

142. Greenblatt, D.J.; Harmatz, J.S.; Friedman, H.; Locniskar, A.; Shader, R.I. A large-sample study of diazepam pharmacokinetics. Ther. Drug Monit. 1989, 11, 652-657. [CrossRef] 
143. Lamson, M.J.; Sitki-Green, D.; Wannarka, G.L.; Mesa, M.; Andrews, P.; Pellock, J. Pharmacokinetics of diazepam administered intramuscularly by autoinjector versus rectal gel in healthy subjects: A phase I, randomized, open-label, single-dose, crossover, single-centre study. Clin. Drug Investig. 2011, 31, 585-597. [CrossRef] [PubMed]

144. Damhoff, H.; McCune, C.L. Barbiturates in the Pediatric ICU. In Sedation and Analgesia for the Pediatric Intensivist; Kamat, P.P., Berkenbosch, J.W., Eds.; Springer International Publishing: Cham, Germany, 2020; pp. 85-94.

145. Löscher, W.; Rogawski, M.A. How theories evolved concerning the mechanism of action of barbiturates. Epilepsia 2012, 53 (Suppl. 8), 12-25. [CrossRef]

146. Wada, D.R.; Björkman, S.; Ebling, W.F.; Harashima, H.; Harapat, S.R.; Stanski, D.R. Computer simulation of the effects of alterations in blood flows and body composition on thiopental pharmacokinetics in humans. Anesthesiology 1997, 87, 884-899. [CrossRef]

147. Westrin, P.; Jonmarker, C.; Werner, O. Thiopental requirements for induction of anesthesia in neonates and in infants one to six months of age. Anesthesiology 1989, 71, 344-346. [CrossRef]

148. Jonmarker, C.; Westrin, P.; Larsson, S.; Werner, O. Thiopental requirements for induction of anesthesia in children. Anesthesiology 1987, 67, 104-107. [CrossRef] [PubMed]

149. Russo, H.; Bressolle, F. Pharmacodynamics and pharmacokinetics of thiopental. Clin. Pharmacokinet. 1998, 35, 95-134. [CrossRef] [PubMed]

150. Mellion, S.A.; Bennett, K.S.; Ellsworth, G.L.; Moore, K.; Riva-Cambrin, J.; Metzger, R.R.; Bratton, S.L. High-dose barbiturates for refractory intracranial hypertension in children with severe traumatic brain injury. Pediatr. Crit. Care Med. 2013, 14, $239-247$. [CrossRef] [PubMed]

151. Marshall, G.T.; James, R.F.; Landman, M.P.; O’Neill, P.J.; Cotton, B.A.; Hansen, E.N.; Morris, J.A., Jr.; May, A.K. Pentobarbital coma for refractory intra-cranial hypertension after severe traumatic brain injury: Mortality predictions and one-year outcomes in 55 patients. J. Trauma 2010, 69, 275-283. [CrossRef]

152. Giovannitti, J.A., Jr.; Thoms, S.M.; Crawford, J.J. Alpha-2 adrenergic receptor agonists: A review of current clinical applications. Anesth. Prog. 2015, 62, 31-39. [CrossRef]

153. Walker, J.; Maccallum, M.; Fischer, C.; Kopcha, R.; Saylors, R.; McCall, J. Sedation using dexmedetomidine in pediatric burn patients. J. Burn Care Res. 2006, 27, 206-210. [CrossRef]

154. Ebert, T.J.; Hall, J.E.; Barney, J.A.; Uhrich, T.D.; Colinco, M.D. The effects of increasing plasma concentrations of dexmedetomidine in humans. Anesthesiology 2000, 93, 382-394. [CrossRef]

155. Pichot, C.; Ghignone, M.; Quintin, L. Dexmedetomidine and clonidine: From second- to first-line sedative agents in the critical care setting? J. Intensive Care Med. 2012, 27, 219-237. [CrossRef]

156. Wolf, A.; McKay, A.; Spowart, C.; Granville, H.; Boland, A.; Petrou, S.; Sutherland, A.; Gamble, C. Prospective multicentre randomised, double-blind, equivalence study comparing clonidine and midazolam as intravenous sedative agents in critically ill children: The SLEEPS (Safety profiLe, Efficacy and Equivalence in Paediatric intensive care Sedation) study. Health Technol. Assess. 2014, 18, 1-212. [CrossRef]

157. Almenrader, N.; Passariello, M.; Coccetti, B.; Haiberger, R.; Pietropaoli, P. Steal-induction after clonidine premedication: A comparison of the oral and nasal route. Paediatr. Anaesth. 2007, 17, 230-234. [CrossRef]

158. Schmidt, A.P.; Valinetti, E.A.; Bandeira, D.; Bertacchi, M.F.; Simões, C.M.; Auler, J.O., Jr. Effects of preanesthetic administration of midazolam, clonidine, or dexmedetomidine on postoperative pain and anxiety in children. Paediatr. Anaesth. 2007, 17, 667-674. [CrossRef] [PubMed]

159. Eisenach, J.C.; De Kock, M.; Klimscha, W. alpha(2)-adrenergic agonists for regional anesthesia. A clinical review of clonidine (1984-1995). Anesthesiology 1996, 85, 655-674. [CrossRef]

160. Ambrose, C.; Sale, S.; Howells, R.; Bevan, C.; Jenkins, I.; Weir, P.; Murphy, P.; Wolf, A. Intravenous clonidine infusion in critically ill children: Dose-dependent sedative effects and cardiovascular stability. Br. J. Anaesth. 2000, 84, 794-796. [CrossRef] [PubMed]

161. De Witte, J.; Sessler, D.I. Perioperative shivering: Physiology and pharmacology. Anesthesiology 2002, 96, 467-484. [CrossRef]

162. Taketomo, C.K.; Hodding, J.H.; Kraus, D.M. Pediatric \& Neonatal Dosage Handbook: An Extensive Resource for Clinicians Treating Pediatric and Neonatal Patients; Lexi-Comp Inc: Hudson, OH, USA, 2017.

163. Capino, A.C.; Miller, J.L.; Johnson, P.N. Clonidine for sedation and analgesia and withdrawal in critically ill infants and children. Pharmacotherapy 2016, 36, 1290-1299. [CrossRef]

164. Weerink, M.A.S.; Struys, M.; Hannivoort, L.N.; Barends, C.R.M.; Absalom, A.R.; Colin, P. Clinical pharmacokinetics and pharmacodynamics of dexmedetomidine. Clin. Pharmacokinet. 2017, 56, 893-913. [CrossRef] [PubMed]

165. Mason, K.P.; O'Mahony, E.; Zurakowski, D.; Libenson, M.H. Effects of dexmedetomidine sedation on the EEG in children. Paediatr. Anaesth. 2009, 19, 1175-1183. [CrossRef] [PubMed]

166. Mason, K.P.; Park, R.S.; Sullivan, C.A.; Lukovits, K.; Halpin, E.M.; Imbrescia, S.T.; Cavanaugh, D.; Prescilla, R.; Fox, V.L. The synergistic effect of dexmedetomidine on propofol for paediatric deep sedation: A randomised trial. Eur. J. Anaesthesiol. 2020. [CrossRef]

167. Erickson, S.J.; Millar, J.; Anderson, B.J.; Festa, M.S.; Straney, L.; Shehabi, Y.; Long, D.A. Dexmedetomidine sedation in mechanically ventilated critically ill children: A pilot randomized controlled trial. Pediatr. Crit. Care Med. 2020, 21, e731-e739. [CrossRef] [PubMed] 
168. Sperotto, F.; Mondardini, M.C.; Dell'Oste, C.; Vitale, F.; Ferrario, S.; Lapi, M.; Ferrero, F.; Dusio, M.P.; Rossetti, E.; Daverio, M.; et al. Efficacy and safety of dexmedetomidine for prolonged sedation in the PICU: A Prospective Multicenter Study (PROSDEX). Pediatr. Crit. Care Med. 2020, 21, 625-636. [CrossRef]

169. Sahinovic, M.M.; Struys, M.; Absalom, A.R. Clinical pharmacokinetics and pharmacodynamics of propofol. Clin. Pharmacokinet. 2018, 57, 1539-1558. [CrossRef]

170. Barr, J.; Egan, T.D.; Sandoval, N.F.; Zomorodi, K.; Cohane, C.; Gambus, P.L.; Shafer, S.L. Propofol dosing regimens for ICU sedation based upon an integrated pharmacokinetic-pharmacodynamic model. Anesthesiology 2001, 95, 324-333. [CrossRef]

171. Hemphill, S.; McMenamin, L.; Bellamy, M.C.; Hopkins, P.M. Propofol infusion syndrome: A structured literature review and analysis of published case reports. Br. J. Anaesth. 2019, 122, 448-459. [CrossRef]

172. Krajčová, A.; Waldauf, P.; Anděl, M.; Duška, F. Propofol infusion syndrome: A structured review of experimental studies and 153 published case reports. Crit. Care 2015, 19, 398. [CrossRef]

173. Timpe, E.M.; Eichner, S.F.; Phelps, S.J. Propofol-related infusion syndrome in critically ill pediatric patients: Coincidence, association, or causation? J. Pediatr. Pharmacol. Ther. 2006, 11, 17-42. [CrossRef]

174. Playfor, S.D.; Venkatesh, K. Current patterns of propofol use in PICU in the United Kingdom and North America. Paediatr. Anaesth. 2004, 14, 501-504. [CrossRef] [PubMed]

175. Mion, G.; Villevieille, T. Ketamine pharmacology: An update (pharmacodynamics and molecular aspects, recent findings). CNS Neurosci. Ther. 2013, 19, 370-380. [CrossRef]

176. Green, S.M.; Krauss, B. Clinical practice guideline for emergency department ketamine dissociative sedation in children. Ann. Emerg. Med. 2004, 44, 460-471. [CrossRef] [PubMed]

177. Wathen, J.E.; Roback, M.G.; Mackenzie, T.; Bothner, J.P. Does midazolam alter the clinical effects of intravenous ketamine sedation in children? A double-blind, randomized, controlled, emergency department trial. Ann. Emerg. Med. 2000, 36, 579-588. [CrossRef] [PubMed]

178. Sherwin, T.S.; Green, S.M.; Khan, A.; Chapman, D.S.; Dannenberg, B. Does adjunctive midazolam reduce recovery agitation after ketamine sedation for pediatric procedures? A randomized, double-blind, placebo-controlled trial. Ann. Emerg. Med. 2000, 35, 229-238. [CrossRef]

179. Dinis-Oliveira, R.J. Metabolism and metabolomics of ketamine: A toxicological approach. Forensic Sci. Res. 2017, 2, 2-10. [CrossRef] [PubMed]

180. Allotey, P.; Reidpath, D.D.; Elisha, D. "Social medication" and the control of children: A qualitative study of over-the-counter medication among Australian children. Pediatrics 2004, 114, e378-e383. [CrossRef] [PubMed]

181. Kishk, O.A.; Simone, S.; Lardieri, A.B.; Graciano, A.L.; Tumulty, J.; Edwards, S. Antipsychotic treatment of delirium in critically ill children: A retrospective matched cohort study. J. Pediatr. Pharmacol. Ther. 2019, 24, 204-213. [CrossRef] [PubMed]

182. Turkel, S.B.; Hanft, A. The pharmacologic management of delirium in children and adolescents. Paediatr. Drugs 2014, 16, 267-274. [CrossRef] [PubMed]

183. Turkel, S.B.; Jacobson, J.R.; Tavaré, C.J. The diagnosis and management of delirium in infancy. J. Child Adolesc. Psychopharmacol. 2013, 23, 352-356. [CrossRef] [PubMed]

184. Poh, Y.N.; Poh, P.F.; Buang, S.N.; Lee, J.H. Sedation guidelines, protocols, and algorithms in PICUs: A systematic review. Pediatr. Crit. Care Med. 2014, 15, 885-892. [CrossRef]

185. Rosenberg, L.; Traube, C. Sedation strategies in children with pediatric acute respiratory distress syndrome (PARDS). Ann. Transl. Med. 2019, 7, 509. [CrossRef]

186. Deeter, K.H.; King, M.A.; Ridling, D.; Irby, G.L.; Lynn, A.M.; Zimmerman, J.J. Successful implementation of a pediatric sedation protocol for mechanically ventilated patients. Crit. Care Med. 2011, 39, 683-688. [CrossRef]

187. Gupta, K.; Gupta, V.K.; Jayashree, M.; Singhi, S. Randomized controlled trial of interrupted versus continuous sedative infusions in ventilated children. Pediatr. Crit. Care Med. 2012, 13, 131-135. [CrossRef]

188. Vet, N.J.; de Wildt, S.N.; Verlaat, C.W.; Knibbe, C.A.; Mooij, M.G.; van Woensel, J.B.; van Rosmalen, J.; Tibboel, D.; de Hoog, M. A randomized controlled trial of daily sedation interruption in critically ill children. Intensive Care Med. 2016, 42, 233-244. [CrossRef]

189. Cunliffe, M.; McArthur, L.; Dooley, F. Managing sedation withdrawal in children who undergo prolonged PICU admission after discharge to the ward. Paediatr. Anaesth. 2004, 14, 293-298. [CrossRef] [PubMed]

190. Keogh, S.J.; Long, D.A.; Horn, D.V. Practice guidelines for sedation and analgesia management of critically ill children: A pilot study evaluating guideline impact and feasibility in the PICU. BMJ Open 2015, 5, e006428. [CrossRef]

191. European Delirium Association; American Delirium Society. The DSM-5 criteria, level of arousal and delirium diagnosis: Inclusiveness is safer. BMC Med 2014, 12, 141. [CrossRef]

192. Smith, H.A.B.; Gangopadhyay, M.; Goben, C.M.; Jacobowski, N.L.; Chestnut, M.H.; Thompson, J.L.; Chandrasekhar, R.; Williams, S.R.; Griffith, K.; Ely, E.W.; et al. Delirium and benzodiazepines associated with prolonged ICU stay in critically ill infants and young children. Crit. Care Med. 2017, 45, 1427-1435. [CrossRef] [PubMed]

193. Traube, C.; Silver, G.; Reeder, R.W.; Doyle, H.; Hegel, E.; Wolfe, H.A.; Schneller, C.; Chung, M.G.; Dervan, L.A.; DiGennaro, J.L.; et al. Delirium in critically ill children: An international point prevalence study. Crit. Care Med. 2017, 45, 584-590. [CrossRef] 
194. Traube, C.; Silver, G.; Gerber, L.M.; Kaur, S.; Mauer, E.A.; Kerson, A.; Joyce, C.; Greenwald, B.M. Delirium and mortality in critically ill children: Epidemiology and outcomes of pediatric delirium. Crit. Care Med. 2017, 45, 891-898. [CrossRef] [PubMed]

195. Smith, H.A.; Fuchs, D.C.; Pandharipande, P.P.; Barr, F.E.; Ely, E.W. Delirium: An emerging frontier in the management of critically ill children. Anesthesiol. Clin. 2011, 29, 729-750. [CrossRef]

196. Silver, G.; Traube, C.; Gerber, L.M.; Sun, X.; Kearney, J.; Patel, A.; Greenwald, B. Pediatric delirium and associated risk factors: A single-center prospective observational study. Pediatr. Crit. Care Med. 2015, 16, 303-309. [CrossRef] [PubMed]

197. van den Boogaard, M.; Schoonhoven, L.; Evers, A.W.; van der Hoeven, J.G.; van Achterberg, T.; Pickkers, P. Delirium in critically ill patients: Impact on long-term health-related quality of life and cognitive functioning. Crit. Care Med. 2012, 40, 112-118. [CrossRef]

198. Alvarez, R.V.; Palmer, C.; Czaja, A.S.; Peyton, C.; Silver, G.; Traube, C.; Mourani, P.M.; Kaufman, J. Delirium is a common and early finding in patients in the pediatric cardiac intensive care unit. J. Pediatr. 2018, 195, 206-212. [CrossRef]

199. Mody, K.; Kaur, S.; Mauer, E.A.; Gerber, L.M.; Greenwald, B.M.; Silver, G.; Traube, C. Benzodiazepines and development of delirium in critically ill children: Estimating the causal effect. Crit. Care Med. 2018, 46, 1486-1491. [CrossRef] [PubMed]

200. Smith, H.A.; Boyd, J.; Fuchs, D.C.; Melvin, K.; Berry, P.; Shintani, A.; Eden, S.K.; Terrell, M.K.; Boswell, T.; Wolfram, K.; et al. Diagnosing delirium in critically ill children: Validity and reliability of the Pediatric Confusion Assessment Method for the Intensive Care Unit. Crit. Care Med. 2011, 39, 150-157. [CrossRef]

201. Schieveld, J.N.; Leroy, P.L.; van Os, J.; Nicolai, J.; Vos, G.D.; Leentjens, A.F. Pediatric delirium in critical illness: Phenomenology, clinical correlates and treatment response in 40 cases in the pediatric intensive care unit. Intensive Care Med. 2007, 33, 1033-1040. [CrossRef]

202. Kamdar, B.B.; Niessen, T.; Colantuoni, E.; King, L.M.; Neufeld, K.J.; Bienvenu, O.J.; Rowden, A.M.; Collop, N.A.; Needham, D.M. Delirium transitions in the medical ICU: Exploring the role of sleep quality and other factors. Crit. Care Med. 2015, 43, 135-141. [CrossRef]

203. Traube, C.; Silver, G.; Kearney, J.; Patel, A.; Atkinson, T.M.; Yoon, M.J.; Halpert, S.; Augenstein, J.; Sickles, L.E.; Li, C.; et al. Cornell Assessment of Pediatric Delirium: A valid, rapid, observational tool for screening delirium in the PICU*. Crit. Care Med. 2014, 42, 656-663. [CrossRef]

204. Kaur, S.; Silver, G.; Samuels, S.; Rosen, A.H.; Weiss, M.; Mauer, E.A.; Gerber, L.M.; Greenwald, B.M.; Traube, C. Delirium and developmental disability: Improving specificity of a pediatric delirium screen. Pediatr. Crit. Care Med. 2020, 21, 409-414. [CrossRef] [PubMed]

205. van Dijk, M.; Knoester, H.; van Beusekom, B.S.; Ista, E. Screening pediatric delirium with an adapted version of the Sophia Observation withdrawal Symptoms scale (SOS). Intensive Care Med. 2012, 38, 531-532. [CrossRef] [PubMed]

206. Ista, E.; van Beusekom, B.; van Rosmalen, J.; Kneyber, M.C.J.; Lemson, J.; Brouwers, A.; Dieleman, G.C.; Dierckx, B.; de Hoog, M.; Tibboel, D.; et al. Validation of the SOS-PD scale for assessment of pediatric delirium: A multicenter study. Crit. Care 2018, 22, 309. [CrossRef]

207. Simone, S.; Edwards, S.; Lardieri, A.; Walker, L.K.; Graciano, A.L.; Kishk, O.A.; Custer, J.W. Implementation of an ICU bundle: An interprofessional quality improvement project to enhance delirium management and monitor delirium prevalence in a single PICU. Pediatr. Crit. Care Med. 2017, 18, 531-540. [CrossRef]

208. Best, K.M.; Wypij, D.; Asaro, L.A.; Curley, M.A. Patient, process, and system predictors of iatrogenic withdrawal syndrome in critically ill children. Crit. Care Med. 2017, 45, e7-e15. [CrossRef] [PubMed]

209. Fisher, D.; Grap, M.J.; Younger, J.B.; Ameringer, S.; Elswick, R.K. Opioid withdrawal signs and symptoms in children: Frequency and determinants. Heart Lung 2013, 42, 407-413. [CrossRef]

210. da Silva, P.S.; Reis, M.E.; Fonseca, T.S.; Fonseca, M.C. Opioid and benzodiazepine withdrawal syndrome in PICU patients: Which risk factors matter? J. Addict. Med. 2016, 10, 110-116. [CrossRef]

211. Amigoni, A.; Vettore, E.; Brugnolaro, V.; Brugnaro, L.; Gaffo, D.; Masola, M.; Marzollo, A.; Pettenazzo, A. High doses of benzodiazepine predict analgesic and sedative drug withdrawal syndrome in paediatric intensive care patients. Acta Paediatr. 2014, 103, e538-e543. [CrossRef]

212. Ávila-Alzate, J.A.; Gómez-Salgado, J.; Romero-Martín, M.; Martínez-Isasi, S.; Navarro-Abal, Y.; Fernández-García, D. Assessment and treatment of the withdrawal syndrome in paediatric intensive care units: Systematic review. Medicine 2020, 99 , e18502. [CrossRef]

213. Madden, K.; Burns, M.M.; Tasker, R.C. Differentiating delirium from sedative/hypnotic-related iatrogenic withdrawal syndrome: Lack of specificity in pediatric critical care assessment tools. Pediatr. Crit. Care Med. 2017, 18, 580-588. [CrossRef] [PubMed]

214. Dominguez, K.D.; Lomako, D.M.; Katz, R.W.; Kelly, H.W. Opioid withdrawal in critically ill neonates. Ann. Pharmacother. 2003, 37, 473-477. [CrossRef]

215. Tobias, J.D. Dexmedetomidine to treat opioid withdrawal in infants following prolonged sedation in the pediatric ICU. J. Opioid Manag. 2006, 2, 201-205. [CrossRef] [PubMed]

216. Warner, D.O.; Zaccariello, M.J.; Katusic, S.K.; Schroeder, D.R.; Hanson, A.C.; Schulte, P.J.; Buenvenida, S.L.; Gleich, S.J.; Wilder, R.T.; Sprung, J.; et al. Neuropsychological and behavioral outcomes after exposure of young children to procedures requiring general anesthesia: The Mayo Anesthesia Safety in Kids (MASK) study. Anesthesiology 2018, 129, 89-105. [CrossRef] 
217. McCann, M.E.; de Graaff, J.C.; Dorris, L.; Disma, N.; Withington, D.; Bell, G.; Grobler, A.; Stargatt, R.; Hunt, R.W.; Sheppard, S.J.; et al. Neurodevelopmental outcome at 5 years of age after general anaesthesia or awake-regional anaesthesia in infancy (GAS): An international, multicentre, randomised, controlled equivalence trial. Lancet 2019, 393, 664-677. [CrossRef]

218. Ing, C.; Jackson, W.M.; Zaccariello, M.J.; Goldberg, T.E.; McCann, M.E.; Grobler, A.; Davidson, A.; Sun, L.; Li, G.; Warner, D.O. Prospectively assessed neurodevelopmental outcomes in studies of anaesthetic neurotoxicity in children: A systematic review and meta-analysis. Br. J. Anaesth. 2021, 126, 433-444. [CrossRef] [PubMed]

219. Kocek, M.; Wilcox, R.; Crank, C.; Patra, K. Evaluation of the relationship between opioid exposure in extremely low birth weight infants in the neonatal intensive care unit and neurodevelopmental outcome at 2 years. Early Hum. Dev. 2016, 92, 29-32. [CrossRef]

220. Ng, E.; Taddio, A.; Ohlsson, A. Intravenous midazolam infusion for sedation of infants in the neonatal intensive care unit. Cochrane Database Syst. Rev. 2017, 1, Cd002052. [CrossRef]

221. Guerra, G.G.; Robertson, C.M.; Alton, G.Y.; Joffe, A.R.; Cave, D.A.; Dinu, I.A.; Creighton, D.E.; Ross, D.B.; Rebeyka, I.M. Neurodevelopmental outcome following exposure to sedative and analgesic drugs for complex cardiac surgery in infancy. Paediatr. Anaesth. 2011, 21, 932-941. [CrossRef] [PubMed]

222. Garcia Guerra, G.; Robertson, C.M.; Alton, G.Y.; Joffe, A.R.; Cave, D.A.; Yasmin, F.; Dinu, I.A.; Creighton, D.E.; Ross, D.B.; Rebeyka, I.M. Neurotoxicity of sedative and analgesia drugs in young infants with congenital heart disease: 4-year follow-up. Paediatr. Anaesth. 2014, 24, 257-265. [CrossRef] [PubMed]

223. Marra, A.; Ely, E.W.; Pandharipande, P.P.; Patel, M.B. The ABCDEF bundle in critical care. Crit. Care Clin. 2017, 33, 225-243. [CrossRef] [PubMed]

224. Walker, T.C.; Kudchadkar, S.R. Early mobilization in the pediatric intensive care unit. Transl. Pediatr. 2018, 7, 308-313. [CrossRef]

225. Manning, J.C.; Pinto, N.P.; Rennick, J.E.; Colville, G.; Curley, M.A.Q. Conceptualizing post intensive care syndrome in children-the PICS-p framework. Pediatr. Crit. Care Med. 2018, 19, 298-300. [CrossRef] [PubMed]

226. Herrup, E.A.; Wieczorek, B.; Kudchadkar, S.R. Characteristics of postintensive care syndrome in survivors of pediatric critical illness: A systematic review. World J. Crit. Care Med. 2017, 6, 124-134. [CrossRef] [PubMed]

227. Andelic, N.; Bautz-Holter, E.; Ronning, P.; Olafsen, K.; Sigurdardottir, S.; Schanke, A.K.; Sveen, U.; Tornas, S.; Sandhaug, M.; Roe, C. Does an early onset and continuous chain of rehabilitation improve the long-term functional outcome of patients with severe traumatic brain injury? J. Neurotrauma 2012, 29, 66-74. [CrossRef]

228. Jacobs, B.R.; Salman, B.A.; Cotton, R.T.; Lyons, K.; Brilli, R.J. Postoperative management of children after single-stage laryngotracheal reconstruction. Crit. Care Med. 2001, 29, 164-168. [CrossRef]

229. Wieczorek, B.; Ascenzi, J.; Kim, Y.; Lenker, H.; Potter, C.; Shata, N.J.; Mitchell, L.; Haut, C.; Berkowitz, I.; Pidcock, F.; et al. PICU up!: Impact of a quality improvement intervention to promote early mobilization in critically ill children. Pediatr. Crit. Care Med. 2016, 17, e559-e566. [CrossRef] [PubMed]

230. Renew, J.R.; Ratzlaff, R.; Hernandez-Torres, V.; Brull, S.J.; Prielipp, R.C. Neuromuscular blockade management in the critically Ill patient. J. Intensive Care 2020, 8, 37. [CrossRef] [PubMed]

231. Marini, J.J. Early phase of lung-protective ventilation: A place for paralytics? Crit. Care Med. 2006, 34, 2851-2853. [CrossRef]

232. Papazian, L.; Forel, J.M.; Gacouin, A.; Penot-Ragon, C.; Perrin, G.; Loundou, A.; Jaber, S.; Arnal, J.M.; Perez, D.; Seghboyan, J.M.; et al. Neuromuscular blockers in early acute respiratory distress syndrome. N. Engl. J. Med. 2010, 363, 1107-1116. [CrossRef] [PubMed]

233. Slutsky, A.S. Neuromuscular blocking agents in ARDS. N. Engl. J. Med. 2010, 363, 1176-1180. [CrossRef] [PubMed]

234. deBacker, J.; Hart, N.; Fan, E. Neuromuscular blockade in the 21st century management of the critically ill patient. Chest 2017, 151, 697-706. [CrossRef] [PubMed]

235. Zuppa, A.F.; Curley, M.A.Q. Sedation analgesia and neuromuscular blockade in pediatric critical care: Overview and current landscape. Pediatr. Clin. N. Am. 2017, 64, 1103-1116. [CrossRef]

236. Stevens, R.D.; Dowdy, D.W.; Michaels, R.K.; Mendez-Tellez, P.A.; Pronovost, P.J.; Needham, D.M. Neuromuscular dysfunction acquired in critical illness: A systematic review. Intensive Care Med. 2007, 33, 1876-1891. [CrossRef] [PubMed]

237. Huang, D.T.; Papazian, L. Is cisatracurium the neuromuscular blocking agent of choice in acute respiratory distress syndrome? Am. J. Respir. Crit. Care Med. 2018, 197, 849-850. [CrossRef]

238. Reich, D.L.; Hollinger, I.; Harrington, D.J.; Seiden, H.S.; Chakravorti, S.; Cook, D.R. Comparison of cisatracurium and vecuronium by infusion in neonates and small infants after congenital heart surgery. Anesthesiology 2004, 101, 1122-1127. [CrossRef]

239. Isenstein, D.A.; Venner, D.S.; Duggan, J. Neuromuscular blockade in the intensive care unit. Chest 1992, 102, 1258-1266. [CrossRef] [PubMed]

240. Murray, M.J.; DeBlock, H.; Erstad, B.; Gray, A.; Jacobi, J.; Jordan, C.; McGee, W.; McManus, C.; Meade, M.; Nix, S.; et al. Clinical practice guidelines for sustained neuromuscular blockade in the adult critically ill patient. Crit. Care Med. 2016, 44, $2079-2103$. [CrossRef] [PubMed] 